\title{
Povijesni i tehnološki razvoj genetičkoga inženjerstva u Hrvatskoj
}

\author{
Vlatka Godinić Mikulčić \\ Agencija za mobilnost i programe Europske unije \\ vgodinic@yahoo.com
}

SAŽETAK: Rad donosi pregled pojmova i spoznaja o genetičkom inženjerstvu te njegova razvoja u drugoj polovici XX. stoljeća do danas u svijetu i u Hrvatskoj. Genetičko inženjerstvo je naziv koji je pretrpio najveće pojmovne deformacije u biologiji i stoga su u radu jednoznačno objašnjeni važni pojmovi. Kako podatci i dokumentacija o genetičkom inženjerstvu u širem opsegu nisu dostupni javnosti, u radu se donosi sustavan pregled njegova razvoja u Hrvatskoj te su prikazane uloge pojedinaca, njihove interakcije i doprinosi. Već su u 1970-ima hrvatska farmaceutska industrija, kao i istraživačke institucije u Hrvatskoj, bile poprište zamaha biotehnologije i genetičkoga inženjerstva u istraživanju i razvoju proizvoda. Različite istraživačke grupe, većinom okupljene oko sastavnica Sveučilišta u Zagrebu (napose Prehrambeno-biotehnološkoga fakulteta i Prirodoslovno-matematičkoga fakulteta), Instituta Ruđer Bošković i PLIVE, rabe tehnologiju rekombinantne DNA za svoja osnovna istraživanja. Osim kronologije zbivanja povezanih s temom genetičkoga inženjerstva, rad opisuje i zasluge znanstvenika (M. Demereca, V. Johanides, M. Alačević, Ž. Trgovčevića, Ž. Kućana, S. Jelaske, V. Gamulin, V. Delića, I. Weygand-Đurašević, Z. Zgage, S. Jelenića, i dr.) u području genetičkoga inženjerstva.

Ključne riječi: genetičko inženjerstvo; gen; tehnologija rekombinantne DNA; vektori; kloniranje; farmaceutska industrija; biotehnologija

\section{Uvod}

Predmet genetičkoga inženjerstva, geni, materijalne su jedinice nasljeđivanja, dijelovi molekula deoksiribonukleinske kiseline (DNA ${ }^{1}$ ) koji nose informaciju nasljednih osobina od roditelja na potomstvo. Genetika je biološka znanost koja istražuje naslje-

1 Iako su DNA, RNA (ribonukleinska kiselina) i imena ostalih makromolekula često nastajala kao kratice engleskih naziva, danas ih smatramo simboličkim imenima pa se ona ne prevode, već se koriste u izvornome obliku. Hrvatske su kratice stoga istovjetne međunarodnima. Npr. pojam deoksiribonukleinske kiseline obuhvaćen je imenom DNA, a ne DNK itd. Budući da su prvotni akronimi postali službenim, autonomnim imenima, oni se ne »ispisuju«, već se koriste u istom, nepromijenjenom obliku i od njih se nadalje stvaraju izvedenice. Podatci dobavljeni s mrežne stranice »Genetički leksikon« (»Genetikon«) (http://genetikon.biol.pmf.hr/). 
đivanje i raznolikost genetičke informacije. Istražuje kako se prenose svojstva roditelja na potomstvo, zbog čega nasljedna svojstva kod jedinki istih roditelja variraju, koji čimbenici određuju ta svojstva, na koji se način svojstva mijenjaju i stječu nova te kako se rezultati tih istraživanja mogu iskoristiti u medicini, stočarstvu, poljoprivredi, farmaceutskoj industriji. Činjenica je da se genetičko inženjerstvo temelji na brojnim znanstvenim otkrićima i spoznajama iz genetike i molekularne biologije koja se odnose na nasljeđivanje u živih bića, a bila su poznata i prije 1970-ih, od kada se počelo razmišljati o mogućnosti spajanja dviju molekula DNA dobivenih iz različitih organizama in vitro, ${ }^{2}$ tj. u epruveti, te o unošenju u određeni organizam domaćina u kojem bi ta hibridna molekula DNA izrazila svoja svojstva.

Kako bismo o tehnologiji rekombinantne DNA, a posebno o tehnologiji genetičkoga inženjerstva u Hrvatskoj mogli smisleno razgovarati, potrebno je prije rasprave utvrditi koji se pojmovi pod tim nazivima kriju. Hrvatski jezik bilježi obilje leksički praznih i nedorečenih mjesta u oblikovanju i usustavljivanju znanstvenoga genetičkog nazivlja uzrokovanih ponajprije izravnim preuzimanjem toga nazivlja iz engleskoga jezika. Dodatnu poteškoću čini naglašeno progresivan razvoj genetike i genetičkoga inženjerstva, brzina oblikovanja novih naziva u toj struci i svakako znanstvena produkcija hrvatskih znanstvenika koji radove objavljuju poglavito na engleskome jeziku. Rječotvornim rješenjima i uskladi jezičnih zakonitosti i stručnih potraživanja uvelike su pridonijele Mirjana Pavlica i Petra Korać iz Zavoda za molekularnu biologiju Prirodoslovno-matematičkoga fakulteta (PMF), u suradnji s Odsjekom za kroatistiku Filozofskoga fakulteta Sveučilišta u Zagrebu (Bernardina Petrović) i Ministarstvom kulture (Ana Vraneša), u sklopu projekta »Genetički leksikon«, koji je financirala Hrvatska zaklada za znanost (putem natječaja »Izgradnja hrvatskoga strukovnog nazivlja $\ll)^{3}$.

Genetičko inženjerstvo pretrpjelo je velike pojmovne deformacije u biologiji. Važna je pojmovna razlika između genetičkoga i genskoga inženjerstva. Može se reći da genetičko inženjerstvo uključuje niz laboratorijskih postupaka i tehnika koji omogućavaju izdvajanje ili sintezu točno određenoga gena ili odsječka gena, njegovu analizu i modifikacije (izmjene, preinačivanje), te ponovno uvođenje i ekspresiju u isti ili neki drugi organizam ili stanice. Ispravno je reći genetičko inženjerstvo, a ne gensko, što upućuje da je organizam izmijenjen, preinačen, oplemenjen metodama genetike i genetičkoga inženjerstva (tehnologije rekombinantne DNA). U sadržajno-istovrsnom smislu, tehnologija rekombinantne DNA (rDNA) predstavlja niz molekularno-genetičkih metoda uz pomoć kojih je moguće preinačiti deoksiribonukleinske kise-

2 in vitro - koji se provodi izvan živoga sustava ili organizma; in vivo - koji se provodi unutar organizma

»Genetički leksikon« (»Genetikon«) (http://genetikon.biol.pmf.hr/). 
line (DNA) s ciljem izradbe hibridne (kimerne) molekule DNA od posebnog interesa koja se može ugraditi u genom stanice uz pomoć tzv. vektora. Vektori su plazmidne ili virusne nukleinske kiseline koji imaju svojstvo replikacije u određenom domaćinu te imaju uklonjene gene za virulenciju. Uvažavajući te činjenice, treba razumjeti korištenje pridjeva »genski«, »genetski«, »genomski« i »genetički«. Pridjev »genski« moguće je primijeniti kod opisa svojstava koja pripadaju samomu genu, koja se odnose samo na njega - npr. »genska« sekvencija (slijed) ili »genska« mutacija. Često se takav oblik zamjenjuje genitivom: sekvencija ili mutacija gena. Pridjev "genetski« može se koristiti u dvama slučajevima - kad se odnosi na genezu (ispravan je izraz »filogenetsko« stablo) ili kad se koristi za opis rezultata djelovanja gena (npr. »/mono/ genetska« bolest; Korać 2018: 69). Pridjev »genomski« rijetko se koristi, iako je u velikom broju slučajeva i najprecizniji i najtočniji opis onoga što je svojstvo samoga genoma (npr. »genomske« regije). Pridjev »genetički« može se koristiti samo onda kada se opisuju genetika kao grana biologije ili njezin rezultat (»genetička« definicija, »genetičko« inženjerstvo, »genetičko« istraživanje i sl.).

Geni su materijalne jedinice nasljeđivanja, a otkrio ih je 1865. Gregor Mendel, utemeljitelj genetike. Po svojoj molekularnoj strukturi, geni su dijelovi vrlo dugačkih molekula DNA, sastavljeni od četiriju tipova osnovnih jedinica, nukleotida, koje označavaju slova genetičkoga teksta $(\mathrm{A}, \mathrm{T}, \mathrm{G} \text { i C })^{4}$, a nose informaciju za protein ili molekulu ribonukleinske kiseline (RNA). Molekule DNA podložne su mutacijama. Povijest otkrića i istraživanja mutacija gena počinje, za svoje doba, revolucionarnim opažanjima krajem XIX. i početkom XX. st., usporedno s reafirmacijom mendelizma. Termin mutacija, u značenju promjene u nukleotidnoj sekvenciji DNA, prvi je koristio Nizozemac Hugo de Vries, primijetivši da jedinke vrste Lamarckov noćurak ili večernja jagorčevina (lat. Oenothera lamarckiana) pokazuju veliku promjenljivost u eksperimentima hibridizacije koja se ne može pripisati kombiniranju mendelovskih gena. Spontano su se pojavljivale biljke s osobinama kakvih nije bilo u prethodnim generacijama. De Vries je zaključio da su spontane nove varijante posljedica materijalnih promjena u genima, nazvavši ih mutacijama. Novonastale odlike ponašale su se po Mendelovim pravilima, što je dokazivalo da se zaista radi o izmijenjenim genima. Hermann Muller pokazao je elegantnim pokusima na vinskoj mušici da radijacija izaziva mutiranje gena (Muller 1927: 66). Sredina, dakle, itekako utječe na promjene u nasljednom materijalu. Tijekom dalinjega obogaćivanja znanja o

4 Adenin je purinska baza u molekulama DNA i RNA koja stvara vodikove veze s komplementarnim bazama timinom i uracilom; međunarodna i hrvatska kratica A. Timin je pirimidinska baza u molekuli DNA koja stvara vodikove veze s komplementarnom bazom adeninom; međunarodna i hrvatska kratica T. Gvanin je purinska baza u molekulama DNA i RNA koja stvara vodikove veze s komplementarnom bazom citozinom; međunarodna i hrvatska kratica G. Citozin je pirimidinska baza u molekulama DNA i RNA koja stvara vodikove veze s komplementarnom bazom gvaninom; međunarodna i hrvatska kratica $\mathrm{C}$. 
mutacijama i o mutagenezi, procesu njihova nastanka, utvrđeno je da različiti faktori iz okoline organizama uzrokuju mutacije, djeluju kao mutageni. Evolucijski napredak vrste ovisi o povremenoj sposobnosti gena da mutiraju. Genske ili točkaste mutacije nastaju u somatskim i generativnim stanicama. Ponekad genske mutacije mogu biti štetne, a mnoge su letalne. Mutacije su najčešće recesivne jer je u heterozigota prisutan i normalni alel gena, pa je mutirani alel sakriven iza funkcije normalnoga. Mutacije nastaju spontano ili su inducirane. Spontane mutacije najčešće nastaju zbog grešaka u replikaciji DNA (primjerice zbog tautomerne promjene baza). Primjerice tautomerni imino-oblik baze citozina sparuje se s adeninom, što nakon replikacije rezultira mutacijom (par CG zamijenjen parom AT), a inducirane mutacije nastaju djelovanjem npr. fizikalnih i kemijskih mutagena. Genom nekoga organizma jest njegova cjelokupna DNA organizirana u kromosome, vidljive u staničnoj jezgri s pomoću mikroskopa kao jasno razlučene strukturne jedinice samo za diobe stanice. Izvan diobenoga procesa kromosomi tvore nježnu nitastu tvorevinu, tzv. kromatinsku mrežicu stanične jezgre. Molekula DNA jednoga jedinog haploidnoga seta ljudskih kromosoma duga je 1,5 m (Kućan 1999: 11).

Genetički izmijenjen ili preinačen organizam (engl. genetically modified organism) jest organizam u koji je unesen genomski materijal korištenjem tehnologije rekombinantne DNA, tj. metodama genetičkoga inženjerstva (međunarodna kratica GMO). Hrvatska je kratica istovjetna međunarodnoj, a nerijetko se može upotrijebiti izraz GM-organizam. Kao sinonim za GM-organizam koristi se pojam »transgeni organizam«, a to je organizam koji u svojim stanicama sadržava transgen (gen koji potječe iz nekoga drugog organizma/vrste). Pojam kloniranje obuhvaća prirodne ili umjetne postupke za dobivanje klonova pojedinih organizama. Klon je skup genetički jednakih individua, stanica ili molekula identičnih nekom prvotnom organizmu, stanici ili molekuli koje su nastale nespolno (aseksualno), vegetativno ili na temelju diploidne partenogeneze (tj. razvojem zametka iz jajne stanice bez oplodnje), ili, kod biljaka apomiksije. Klon organizama i stanica ne može nastati oplodnjom, nego isključivo diobom. Tako npr. potomci koji su nastali diobom iz jedne papučice ili jedne bakterije čine klon. Ipak, iako su klonovi vrlo slični svojim genetičkim izvorima, oni im nisu potpuno identični zbog uobičajenih mutacija koje se događaju u kromosomskom i mitohondrijskom genomu, zbog individualnih varijacija u epigenetičkom statusu, kao i zbog utjecaja npr. citoplazme jajašca primatelja. Kada govorimo o kloniranju, često najprije pomislimo na kloniranje pod kontrolom čovjeka. U javnosti je manje poznato da se kloniranje svakodnevno događa u prirodi. Kloniranje je dobro poznat prirodan postupak dobivanja populacije identičnih jedinki naročito u biljnih organizama (npr. prilikom razmnožavanja jagoda rasađivanjem ogranaka materinskih biljaka nastaju isto tako klonovi). Tehnikama kulture biljnih stanica i tkiva u uvjetima in vitro mnoge biljne vrste mogu se klonirati u laboratoriju te iz malih dijelova biljke ili čak iz pojedinih biljnih stanica uzgojiti čitavu biljku. Takve se regene- 
rirane biljčice mogu iz epruvete prenijeti u zemlju, a predstavljaju velik broj genetički identičnih potomaka - klonova majčinske biljke. Za prvo nastojanje regeneracije mrkve iz diferenciranoga tkiva korijena zaslužan je britanski botaničar Frederick Campion Steward 1952. Kultura biljnoga tkiva danas osnova je za razvoj i primjenu mnogih metoda biljne biotehnologije.

\section{Primjena genetičkoga inženjerstva te povijesni razvoj u svijetu}

\section{1. Primjena genetičkoga inženjerstva}

Tehnologija rekombinantne DNA danas je vrlo raširena te nalazi primjenu u biotehnologiji, biokemijskom inženjerstvu, medicini, poljoprivredi te $u$ fundamentalnim $\mathrm{i}$ primijenjenim znanstvenim istraživanjima. $U$ biotehnologiji genetičko se inženjerstvo koristi u proizvodnji lijekova (biofarmaceutika), za povećanje prinosa određenoga metabolita, konstrukciju GM-biljaka te poboljšanje svojstava hrane i drugih industrijskih proizvoda. U medicini se genetičko inženjerstvo koristi za razvoj novih lijekova, proizvodnju hormona, proizvodnju velikih količina terapeutskih proteina za liječenje bolesti (inzulin, interferon, hormon rasta, čimbenici rasta, čimbenici zgrušavanja), cjepiva (protiv hepatitisa $\mathrm{B}$, herpesa, bjesnoće), dijagnostici (proizvodnja protutijela), sekvenciranje humanih genoma te identifikaciju gena za različite bolesti. Biološki lijek, u užem smislu biofarmaceutik, lijek je čija je djelatna tvar biološka tvar, koja se proizvodi ili izlučuje iz biološkoga izvora (ljudskog, životinjskog ili mikrobiološkog). Biološki lijekovi mogu biti imunološki lijekovi (cjepiva i serumi, toksini, proizvodi alergena), lijekovi iz ljudske krvi ili ljudske plazme (npr. albumin ili imunoglobulini), lijekovi dobiveni biotehnološkim postupcima (postupcima koji uključuju uporabu živih sustava ili organizama), lijekovi za naprednu terapiju (koji se temelje na genskoj terapiji, terapiji somatskim stanicama ili tkivnom inženjerstvu) i ostali lijekovi dobiveni iz biološkoga izvora (npr. heparin ili pankreatin). Dakle, u biološke lijekove spadaju monoklonska protutijela, hormoni, citokini, čimbenici zgrušavanja krvi i cjepiva. Neki od njih su proizvedeni biotehnološkim metodama, a često je riječ o proteinima proizvedenima metodama genetičkoga inženjerstva. Geni koji kodiraju određeni protein, npr., ugrade se u živu stanicu koja počinje proizvoditi željeni protein lijek. Proteini se, potom vrlo složenim postupcima izoliraju, pročišćuju i kao djelatna tvar koriste u proizvodnji određenoga lijeka. Genetičko inženjerstvo pokazalo je svoju snagu na području medicine i farmaceutike te je na tim područjima općeprihvaćeno i dobrodošlo. Međutim, nepovjerenje prema genetičkom inženjerstvu sveprisutno je kada je riječ o proizvodnji GM-hrane. U poljoprivredi se genetičko inženjerstvo upotrebljava za proizvodnju biljaka otpornih na herbicide, sušu, hladnoću, visoku temperaturu, preveliku količinu soli, loše uvjete skladištenja i transporta, te za proizvodnju biljaka bolje prehrambene vrijednosti. Gen za Bt-tok- 
$\sin ($ gen crylAb) iz bakterije Bacillus thuringiensis uveden je u više od 50 biljnih vrsta, a ekspresija ovoga gena pruža biljci zaštitu od insekata (npr. kukuruznoga moljca Ostrinia nubillalis). Međutim, postoje istraživanja koja dokazuju kako Bt-kukuruz (s ugrađenim genom iz B. thuringiensis), otpušta Bt-toksin u tlo i negativno djeluje na kolonizaciju tla mikorizama, pa time i na plodnost tla (Castaldini 2005: 6719). Trenutačno su na tržištu dostupne različite vrste genetički preinačenih biljaka poput soje, riže, rajčice, kukuruza, krumpira, duhana, pamuka, dinje, papaje i dr. Prva transgena rajčica pod nazivom Flavr Savr na tržištu je od 1994; ima ugrađen gen s reduciranom aktivnošću enzima poligalakturonaze (normalna aktivnost enzima uzrokuje prerano sazrijevanje ploda). U industriji se primjenjuju genetički modificirane bakterije koje razgrađuju toksični otpad, genetički modificirani kvasci koji koriste celulozu za proizvodnju glukoze i alkohola za gorivo, u uzgoju alga u marikulturi. Trenutačno je u procesu istraživanja ili patentiranja oko 30-ak vrsta GM-riba i GM-školjkaša. U Europskoj uniji proizvođačima hrane trenutačno nije u interesu proizvodnja životinja kloniranjem u svrhu proizvodnje hrane, no ipak su istaknuli kako je za održavanje konkurentnosti neophodan pristup genima visoke učinkovitosti, uključujući materijal za razmnožavanje klonova. To znači da, ukoliko je kloniranje provedeno u trećim zemljama, europskim proizvođačima ostaje mogućnost za uzgoj potomstva kloniranih životinja, kao i stavljanje hrane takva podrijetla na tržište.

U želji da pronađu još precizniji i učinkovitiji alat za modifikaciju gena, znanstvenici su razvili mehanizam za uređivanje genoma posredovan bakterijskim nukleazama, nazvan sustavom CRISPR-Cas (engl. Clustered Regularly Interspaced Short Palindromic Repeats-CRISPR-associated). Sustav je prvotno otkriven u bakterija koje ga koriste u obrani stanice domaćina od strane DNA, primjerice prilikom borbe protiv bakteriofaga. Do sada su tehnologijom CRISPR-Cas genetički modificirani neki usjevi, ali postoje i neka istraživanja učinkovitosti tehnologije u liječenju ljudskih bolesti. Tijekom 2019. objavljeni su preliminarni rezultati studije liječenja dvaju pacijenata oboljelih od srpaste anemije i talasemije sustavom CRISPR-Cas, koji su uputili na znatno poboljšanje krvne slike $u$ oba slučaja nekoliko mjeseci od početka genske terapije ${ }^{5}$. Tehnologija CRISPR-Cas došla je doduše na loš glas u kontekstu humane medicine 2018., kad je kineski znanstvenik He Jiankui genetički modificirao tri ljudska embrija, s ciljem stvaranja imunosti na HIV, kršeći ne samo medicinsku etiku već i zakonsku regulativu, za što je osuđen na tri godine zatvora ${ }^{6}$. Neočekivana je primjena tehnologije CRISPR-Cas u pivarstvu. Potražnja za hmeljem drastično raste, primjerice samo je u SAD-u tijekom protekloga desetljeća utrostručena prodaja hmelja. Linalol i geraniol su primarni spojevi odgovorni za intenzivan, hmeljasti okus piva, međutim njihova koncentracija u hmelju može znatno varirati,

5 https://investors.vrtx.com/news-releases/news-release-details/crispr-therapeutics-and-vertexannounce-positive-safety-and (pristupljeno 26. VI. 2020).

6 https://www.nature.com/articles/d41586-020-00001-y (pristupljeno 26. VI. 2020). 
što ima negativan učinak na ponovljivost kvalitete piva. Denby i suradnici (Denby 2018: 965) sustavom CRISPR-Cas genetički su modificirali kvasac Saccharomyces cervesiae, koji proizvodi željene monoterpene za hmeljasti okus piva. Mogućnosti sustava CRISPR-Cas iznimno su velike te ne staju na konvencionalnoj percepciji genske modifikacije. Neobična je i primjena sustava CRISPR-Cas u oživljavanju izumrlih vrsta. U projektu Revive \& Restore ${ }^{7}$ znanstvenici rade na oživljavanju izumrloga sjevernoameričkoga goluba Ectopistes migratorius s pomoću tehnike CRISPR-Cas. Do danas su uspjeli dobiti transgeničnoga goluba, međutim u haploidnim stanicama jedinke tek jedna od sto tisuća nosi željeni gen, što drastično smanjuje izglede za transgeničnim potomstvom. Usprkos tome, radi se o napretku u ostvarenju projekta, a sadašnje projekcije očekuju izlijeganje prvih novovjekovnih Ectopistes migratorius do 2025 (Kovačić 2019: 202).

Jedna od mogućih primjena genetičkoga inženjerstva terapijsko je kloniranje stanica, organa i tkiva za transplantaciju. Terapijsko kloniranje drugi je izraz za postupak poznat kao »prijenos jezgre somatske stanice« (engl. somatic cell nuclear transfer, SCNT), koji se zasniva na izdvajanju DNA iz somatske stanice individue kojoj je potrebna transplantacija, a izolirana DNA zatim se umeće u drugu jajnu stanicu iz koje su prethodno odstranjeni kromosomi. Jajašce tada sadržava pacijentov nasljedni materijal ili genetičku uputu. Potom je stimulirano na diobu i ubrzo nakon toga formira se grozdasta struktura stanica - blastocista. Stanice iz blastociste dalje se iskoriste za dobivanje embrionalnih matičnih stanica, nediferenciranih stanica koje mogu tvoriti široki raspon različitih staničnih razvojnih smjerova (diferencijacija). Za razliku od terapijskoga kloniranja, reproduktivno pak kloniranje ima cilj stvaranja nove osobe jer se novostvoreni embrij stavlja natrag u okoliš maternice, gdje se može razvijati. Podrazumijeva se da je primjena ovakvih postupaka moguća tek nakon savladavanja mnogih imunoloških, metodoloških, tehničkih, etičkih i drugih prepreka. $S$ druge strane, razvoj i perspektive kloniranja često nisu adekvatno praćene spremnošću društva za prijam ostvarenih rezultata. To se naročito odnosi na terminologiju i odredbe u zakonima, a pogotovo na regulativu pojedinih medicinskih postupaka. Dio nesnalaženja možda treba pripisati činjenici da nije jednostavno povući jasnu granicu između pokusa reproduktivnoga (kloniranje individua) i terapijskoga kloniranja (kloniranje stanica i tkiva u medicinske terapeutske svrhe). Teškoće $u$ tom pogledu zadaje podudarnost u metodama rada u ovim istraživanjima.

\section{2. Povijest genetičkoga inženjerstva u svijetu}

Razvoj genetičkoga inženjerstva temelji se na brojnim znanstvenim otkrićima i spoznajama iz genetike i molekularne biologije koja se odnose na nasljeđivanje u živih

7 https://reviverestore.org/ (pristupljeno 26. VI. 2020). 
bića, a bila su poznata i prije 1970-ih kada se počelo razmišljati o mogućnosti spajanja dviju molekula DNA dobivenih iz različitih organizama in vitro, tj. u epruveti, te o unošenju u određeni organizam domaćina gdje bi ta hibridna molekula DNA izrazila svoja svojstva. Opću strukturu DNA poznajemo od 1953. kada su razjašnjene strukture DNA i njezine uloge u nasljeđivanju zahvaljujući Jamesu Watsonu i Francisu Cricku, koji su zajedno s Mauriceom Wilkinsom 1962. dobili Nobelovu nagradu za fiziologiju ili medicinu. Njihovu uspjehu pridonio je rad znanstvenice Rosalind Franklin, koja je u ranim 1950-ima X-zrakama dobila difrakcijske slike DNA, zahvaljujući kojima su Watson i Crick zaključili da DNA ima strukturu dvostruke zavojnice. Otkrićem prostorne građe DNA, 1953. rođena je nova znanstvena disciplina: molekularna biologija. Gotovo usporedno, razvoj genetičkoga inženjerstva započet je otkrićem restrikcijskih endonukleaza godine 1952., enzima koji cijepaju (presijecaju) molekulu DNA na točno određenim redoslijedima nukleotida, čineći usjeke te se mogu koristiti kao »molekularne škare za DNA«. Enzimi restrikcijske endonukleaze (slika 1) nalaze se prirodno u bakterijama kao dio restrikcijsko-modifikacijskoga sustava za obranu od bakteriofaga (virusa koji napadaju bakterije), a za to otkriće švicarski znanstvenik Werner Arber podijelio je Nobelovu nagradu za fiziologiju ili medicinu 1978. s američkim znanstvenicima Danielom Nathansom i Hamiltonom Smithom. Nazivi restrikcijskih endonukleaza potječu od bakterije iz koje su prvotno izolirane, na način da prvo slovo dolazi od roda, druga dva slova u imenu prva su dva slova bakterijske vrste, iza čega može slijediti slovo koje označava soj ili rimski broj, ukoliko je iz tog organizma izolirano više enzima. Npr. naziv restrikcijske endonu-
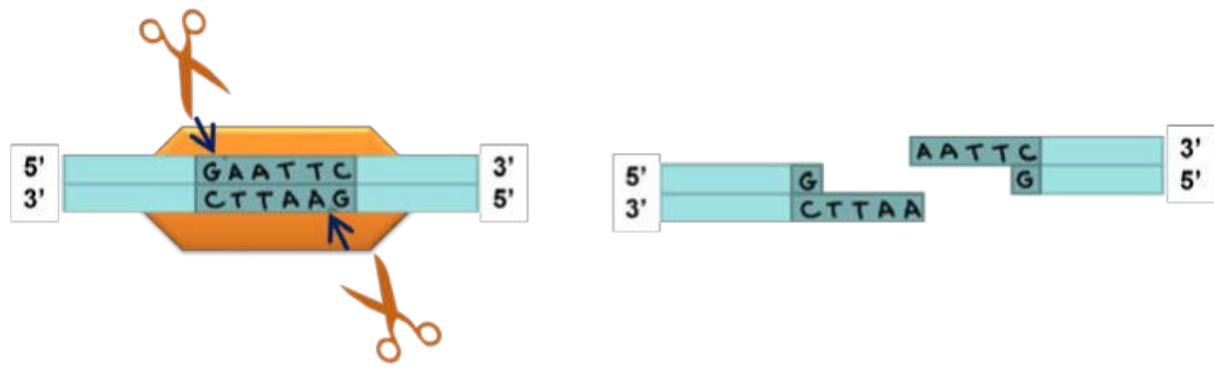

Slika 1. Restrikcijske endonukleaze

Otkriće restrikcijskih endonukleaza dovelo je do razvitka tehnika rekombinantne DNA. Ove tehnike omogućuju spajanje fragmenata DNA iz najrazličitijih izvora s prikladnim molekulama DNA koje se samostalno repliciraju - vektorima. Tako nastale, rekombinantne molekule mogu se klonirati (višestru-

ko umnožiti) unošenjem u stanice domaćina gdje se umnažaju koristeći se staničnim enzimima za replikaciju DNA. Geni uneseni u nove domaćine na ovaj način se mogu i transkribirati i translatirati, tako da se u stanici domaćina pojavljuju strani proteini. Sljedovi baza u molekuli DNA koje prepoznaju ovi enzimi gotovo su uvijek palindromi, dakle sljedovi koji imaju dvostruku os simetrije. Svaki pojedini enzim prepoznaje svoj slijed i presijeca ga se uvijek na isti način. Na slici je prikazano mjesto presijecanja enzima EcoRI. Tako presijecanjem mogu nastajati tupi krajevi ili krajevi koji strše na 5'-kraju ili

3'-kraju. Stršeći krajevi nazivaju se i ljepljivi (kohezivni) krajevi jer se mogu međusobno spariti, stvarajući vodikove veze među bazama. 
kleaze EcoRI potječe iz bakterije Escherichia coli (E. coli), a slovo R predstavlja soj, koji je u ovom slučaju RY13, a prvi je u nizu izoliran iz te bakterije (Godbey 2015: 203).

Sljedeći važan događaj za genetičko inženjerstvo zbio se 1967. otkrićem enzima DNA-ligaza. Enzimi DNA-ligaze mogu pak spajati usjeke nastale u jednom lancu molekule DNA između susjednih nukleotida u molekuli DNA, djelujući kao »molekularno ljepilo«, a dobiveni su ili iz bakterija ili od bakterijskih faga (slika 2). Uporabom DNA-ligaza moguće je fragmentiranu DNA ponovno spajati te su ubrzo ustanovljene metode kojima se molekule DNA mogu ugraditi u specifične genske elemente bakterija i umnožiti u milijardama primjeraka. Sve te spoznaje bile su preduvjet za spajanje dviju molekula DNA in vitro iz različitih organizama u jednu hibridnu (kimernu) molekulu sašivanjem genetičkoga materijala različitoga podrijetla (slika 2). Godine 1972. rođeno je genetičko inženjerstvo - konstruirana je prva molekula DNA in vitro, »rekombinantna" DNA (rDNA), stoga se genetičko inženjerstvo naziva i »tehnologija (metodologija) rekombinantne DNA«. Prvomu je to uspjelo biokemičaru Paulu Bergu, koji je 1980., s Walterom Gilbertom i Frederickom Sangerom
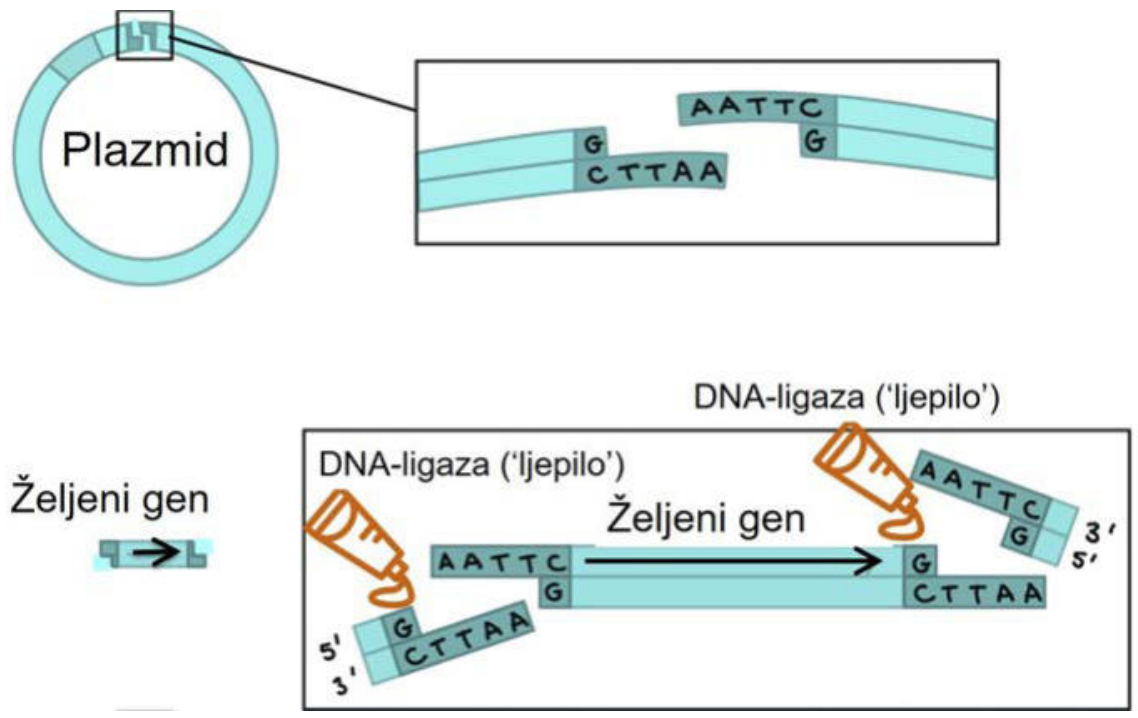

Slika 2. Stvaranje rekombinantne DNA

Jednostavni prikaz stvaranja rekombinantne DNA. Da bismo odsječak DNA koji želimo ispitivati (najčešće neki željeni gen ili više gena) unijeli u novoga domaćina, potrebno ga je ugraditi u odgovarajući vektor. Kao vektori najčešće se koriste plazmidi, koji osiguravaju da se ispitivana DNA replicira u novom domaćinu. $U$ tu svrhu presiječemo ispitivanu DNA i plazmidni vektor istim restrikcijskim enzimom, pri čemu nastaju komplementarni ljepljivi krajevi. Potom povežemo ispitivanu DNA s plazmidnom DNA koristeći enzim DNA-ligazu (koji povezuje slijepljene komplementarne krajeve) i nastaje rekombinantna DNA. Restrikcijski enzimi ne razlikuju sljedove DNA sisavca, kvasca ili kakve bilike od slijeda bakterijske DNA (iako neki enzimi razlikuju metiliranu od nemetilirane DNA i djeluju specifično samo na nemetiliranu DNA), tako da možemo bez problema DNA-ligazom povezivati molekule DNA iz najrazličitijih izvora, pod uvjetom da smo ih presjekli istim restrikcijskim enzimom. 
dobio Nobelovu nagradu za kemiju, za rad na biokemiji nukleinskih kiselina. Daljnjim razvojem genetičkoga inženjerstva omogućeno je uvođenje preciznih genetičkih promjena u žive organizme, uključujući i mogućnost sinteze DNA i prijenosa između različitih organizama (vrsta). Prva modifikacija virusa u svrhu prenošenja stranih gena u stanicu objavljena je 1968., a kao vektor korišten je virus mozaika duhana TMV (engl. tobacco mosaic virus). Nakon toga je, u svrhu prijenosa gena $\mathrm{u}$ stanice sisavaca, konstruiran vektor od virusa SV40 (engl. simian virus 40) u koji je ugrađen gen za globulin zeca te je uspješno unesen u kulturu stanica. Godine 1973. u bakteriju E. coli prvi je put unesena i umnožena rekombinantna DNA te je tako nastala i prva GM-bakterija. Zahvaljujući tome, primjerice, danas se u bakteriji $E$. coli proizvodi ljudski inzulin. Štoviše, inzulin koji se danas koristi nije istovjetan prirodnom ljudskom inzulinu, nego je dodatno izmijenjen i unaprijeđen genetičkim inženjerstvom. U SAD-u je 1976. osnovana tvrtka Genentech Inc, koja je prva u povijesti uspjela eksprimirati ljudski gen u bakteriji (1977) i tako proizvesti hormon somatostatin. Jedna je od glavnih metoda koja se primjenjuje u genetičkom inženjerstvu sekvenciranje - određivanje slijeda nukleotida u DNA. Godine 1977. istodobno su objavljene dvije metode sekvenciranja DNA - Maxam-Gilbertova i Sangerova metoda sekvenciranja. Prvi sekvencirani genom bio je genom bakteriofaga $\Phi X 174$, koji se sastoji od 5368 parova baza, a sekvenciranje je predvodio F. Sanger 1977. godine. Prva GM-bakterija patentirana je 1981. u SAD-u i pripada rodu Pseudomonas (poznata pod nazivom oil-eating bacterium) te ujedno predstavlja prvi patentirani živi organizam. Iste godine konstruiran je i prvi GM-sisavac (miš). Spoznajna znanost koja isključuje patentnu zaštitu i na kojoj se ne može stjecati bogatstvo, na neki je način od toga doba sve manje bila slobodna od poslovnoga svijeta. Nadalje, GM-bilike postaju komercijalno dostupne od 1986. Otkriće tehnike PCR (engl. polymerase chain reaction: lančana reakcija polimerazom) 1983. bilo je ključno za daljnji razvoj eksperimentalnih otkrića u genetičkom inženjerstvu. Lančana reakcija polimerazom omogućuje stvaranje golemoga broja kopija određenoga dijela DNA. Sam razvoj tehnike PCR smanjio je vrijeme potrebno za ugradnju željenoga slijeda DNA i time je mogućnost izvođenja eksperimenata, ali i njihova učinkovitost, postala uvelike dostupna. $\mathrm{Za}$ izum tehnike PCR Kary Mullis i Michael Smith dobili su Nobelovu nagradu za kemiju 1993. godine. Prva genska terapija na čovjeku provedena je 1990. na četverogodišnjoj djevojčici primjenom terapijskoga gena u svrhu liječenja nasljedne monogenske bolesti, teške kombinirane imunodeficijencije koja proizlazi iz manjka enzima adenozin-deaminaze. Projekt ljudskoga genoma, koji je sustavno trajao 1990-2000., pothvat je golemih razmjera kojim je određen slijed nukleotida u ljudskom genomu od gotovo tri milijarde parova baza DNA (Zgaga 2000: 237). Metode genetičkoga inženjerstva omogućile su stvaranje kombinacija gena in vitro te unošenje takvih konstruiranih gena u oplođenu jajnu stanicu metodom mikroinjektiranja. Unošenjem takve jajne stanice u uterus životinje primatelja moguće je dobiti transgene ži- 
votinje. Znanstvenici Roslinova instituta kraj Edinburgha, predvođeni biolozima Ianom Wilmutom i Patrickom Dixonom, 1997. uspjeli su kloniranjem, tj. nespolno (aseksualno), stvoriti prvoga kloniranog sisavca, ovcu Dolly, što je tada bila najveća znanstvena senzacija. Ovca Dolly klonirana je iz somatske stanice odrasle jedinke. Znanstvenici su iz tjelesnih stanica vimena odrasle ovce izdvojili dvostruki (diploidni; 2n) set kromosoma i prenijeli ga u jednu neoplođenu jajnu stanicu druge ovce iz koje su prethodno odstranili njezine kromosome. Takvu diploidnu stanicu koja se normalno počela dijeliti implantirali su u maternicu treće ovce (surogat majke). Odmah je bilo sporno je li Dolly već pri rođenju stara koliko i njena majka, koja je bila izvor genetičkoga materijala. Zna se, naime, da nasljedni materijal u stanicama podliježe izvjesnim procesima starenja. Poslije su kod Dolly primijećeni neki simptomi preranoga starenja, njezine tjelesne stanice bile su »starije« nego što bi odgovaralo njezinoj dobi. Međutim, ona je ipak doživjela ovčju »srednju dob«. Žrtvovana je kad se razboljela od neizlječive upale pluća, u starosti od skoro sedam godina, koja otprilike odgovara ljudskoj starosti od 35 do 40 godina. Prethodno je na prirodan način začela i rodila zdravo, normalno janje. Potom su dobivene i druge transgene životinje koje, npr. u mlijeku, imaju povećane količine važnih lijekova koji se ne mogu dobiti u zadovoljavajućim količinama na druge klasične načine (antitripsin, tkivni aktivator plazminogena, laktoferin i dr.). Također je 1997. konstruirana GM-svinja koja u mlijeko izlučuje humani čimbenik zgrušavanja VIII (Paleyanda 1997: 971). Ovakav pristup u kojem se GM-bilike i životinje koriste kao proizvođači farmaceutskih proizvoda, npr. izlučivanjem u mlijeko, popularno se naziva pharming, a takve životinje mammary bioreactors. Razvojem novih metoda sekvenciranja, odnosno sekvenciranja novih generacija (NGS, od engl. next generation sequencing; sinonim je i masivno paralelno sekvenciranje) u 2005., znatno se povećala brzina sekvenciranja genoma te se smanjili troškovi postupka.

Adaptacije živih organizama koje omogućavaju preživljavanje i razmnožavanje rezultat su prirodne selekcije. Za većinu gena, selekcija alternativnih alela zasniva se na tome koliko pridonose preživljavanju i razmnožavanju nekoga organizma. Naime, »gene drive « (gensko upravljanje; genski pogon) jest pristup, tj. tehnika genetičkoga inženjerstva, ponekad sinonim i za sam genetički element, koji »prkosi« prirodnoj selekciji, glavnom mehanizmu evolucije, i rezultira nasljeđivanjem određenih gena, čak i ako sveukupno nemaju pozitivan utjecaj na domaćina. Oni zaobilaze Mendelova pravila nasljeđivanja - umjesto $50 \%$ vjerojatnosti da će potomak naslijediti određeni alel, za gene drive alele ta se vjerojatnost povećava na $60 \%$, pa čak do $99 \%$. Austin Burt je 2003. prvi predložio ideju o uporabi takvih prirodnih »sebičnih« genetičkih elemenata za ciljano uređivanje genoma i manipulaciju divljih populacija. Eksperimentiranje sa sintetskim gene drive sustavima doživjelo je veliki uzlet nekoliko godina poslije zbog otkrića sustava CRISPR-Cas tehnologije koja je omogućila brže, preciznije i učinkovitije dizajniranje gene drive alela. Aktualna istraživanja bave 
se mogućnostima primjene sintetskih gene drive sustava za suzbijanje malarije modifikacijom populacije komaraca te za kontrolu populacija glodavaca na način da će se geni korisni za neku populaciju s pomoću ovakvih sustava širiti brže i temeljitije nego što to dozvoljava prirodna selekcija. Međutim, gene drive sustavi sa sobom nose i potencijalne opasnosti za ekosustav. Posljednji revolucionarni pomak u primjeni genetičkoga inženjerstva ostvaren je 2012. kad su Jennifer Doudna i Emmanuelle Charpentier otkrile sustav za ciljanu modifikaciju genoma CRISPR-Cas9 (engl. Clustered, Regularly Interspaced Short Palindromic Repeats-CRISPR-associated protein 9). Kao i restrikcijske endonukleaze koje su omogućile razvoj genetičkoga inženjerstva, i sustav CRISPR-Cas prirodno služi bakterijama za obranu od bakteriofaga. Sustav CRISPR-Cas predstavlja adaptivni imunosni sustav bakterija i arheja u borbi protiv bakteriofaga i plazmida (strane DNA). U gotovo svim arhejama i velikom dijelu bakterija, ali ne u virusima ni u eukariotima, otkriveni su određeni geni koji sadržavaju specifične sekvence, čije su zajedničko obilježje ponavljajući sljedovi DNA točno određene veličine (24-40 parova baza), međusobno odijeljeni sljedovima veličine od 20 do 58 parova baza. Naime, bakterija stječe otpornost ugradnjom kratkih fragmenata strane DNA u lokus CRISPR. Bakterije koje prežive infekciju s pomoću CRISPR-Cas sustava pohranjuju fragmente patogene DNA unutar CRISPR lokusa u vlastitom genomu. Ugrađeni fragmenti omogućavaju bakterijama pamćenje i prepoznavanje iste strane DNA u sljedećoj infekciji. Sustav CRISPR-Cas omogućuje još uspješnije, jednostavnije i preciznije uvođenje genetičkih modifikacija u živu stanicu programiranjem sustava CRISPR-Cas u laboratoriju, kao i brojne primjene u genetičkom inženjerstvu.

\section{Razvoj i primjena genetičkoga inženjerstva u Hrvatskoj}

Već 1970-ih, ubrzo nakon otkrića tehnologije rekombinantne DNA u svijetu, hrvatska farmaceutska industrija i istraživačke skupine okupljene oko Instituta Ruđer Bošković (IRB), farmaceutskoga poduzeća PLIVA i sastavnica Sveučilišta u Zagrebu, napose Prehrambeno-biotehnološkoga fakulteta (PBF) i Prirodoslovno-matematičkoga fakulteta (PMF) u Zagrebu, rabile su tehnologiju rDNA za svoja osnovna i primijenjena istraživanja.

\section{1. Genetičko inženjerstvo u hrvatskoj industriji - PLIVIN Istraživački institut}

Pojavom tehnologije rDNA područje terapijskih proteina postalo je najuzbudliivije i najbrže rastuće područje farmaceutske industrije. Terapijski proteini upotrebljavali su se i prije pojave tehnologije rDNA. To su bili proteini životinjskoga podrijetla, kao što su goveđi i svinjski inzulin ili humani proteini, kao što su humani hormon rasta 
i čimbenik zgrušavanja VIII koji su izolirani iz humanoga tkiva ili seruma. PLIVA ${ }^{8}$ je s biotehnologijom započela 1938. kada se iz pankreasa svinje radila ekstrakcija inzulina. Od 1958. biotehnologija se koristi u proizvodnji vitamina, kvasca, vakcina za veterinarsku industrija, a petnaestak godina proizvodili su se industrijski enzimi.

U PLIVINU Istraživačkom institutu, selekcija i mutageneza bile su uobičajene metode rada u preinačivanju mikroorganizama koji sintetiziraju farmaceutski korisne tvari. Tehnologije genetičkoga inženjerstva u najvećoj su se mjeri razvijale i primjenjivale u Odjelu za mikrobnu i molekularnu biologiju, gdje je postojalo dugogodišnje iskustvo u radu na genetici industrijskih mikroorganizama koji sintetiziraju korisne proizvode za ljudsko zdravlje (antibiotici, vitamini, enzimi). Iskustva stečena u istraživanjima na genetici i mutacijama u tih mikroorganizama dala su čvrste temelje i bili su preduvjet za lakšu primjenu i prihvaćanje tehnologija rekombinantne DNA u Hrvatskoj. Stručnjaci i znanstvenici iz PLIVE koji su se bavili molekularnom genetikom prihvatili su tehnologije rekombinantne DNA s ciljem dobivanja proizvodnih mikroorganizama novih svojstava. Neki od njih bili su: Jasenka Pigac (Pigac 1979: 575; 1988: 222), Daslav Hranueli (Hranueli 1983: 401), Vladimir Delić (Delić 1989: 299), Zora Toman i Maja Bilić. Tehnologija rekombinantne DNA u PLIVI

8 PLIVA (akronim od Proizvodnja lijekova i vakcina) farmaceutsko je poduzeće sa sjedištem u Zagrebu. Prethodnik joj je bilo poduzeće Kaštel d.d., osnovano 1921. u Karlovcu, kojemu je prvi predsjednik Odbora dioničarskoga društva Kaštel bio profesor Gustav Janeček. Kaštel se 1927. preselio u Zagreb u novoizgrađenu zgradu na Prilazu baruna Filipovića. Većinski vlasnik tvornice postao je dr. Ladany, koji je 1935. započeo suradnju s Vladimirom Prelogom, poslije dobitnikom Nobelove nagrade za kemiju 1975. Prelog je 1941. otišao u Institut za organsku kemiju na Tehničkoj visokoj školi u Zürichu (ETH Zürich) i tamo nastavio sa znanstvenim radom. God. 1940. osnovan je Banovinski zavod za proizvodnju lijekova biološkoga i kemijskoga sastava (PLIBAH), koji je 1941. preimenovan u Državni zavod za proizvodnju lijekova i vakcina (PLIVA); od 1945. u njegovu je sastavu i tvrtka Kaštel. Ubrzo poslije integracije Kaštela s PLIVOM, farmaceutska se tehnologija počinje naglo razvijati u Hrvatskoj. PLIVIN Istraživački institut utemeljen je 1952. Od 1958. u PLIVI se biotehnologija koristi u proizvodnji vitamina, kvasca, vakcina za veterinarsku industrija, a petnaestak godina od 1981. proizvodili su se industrijski enzimi za proizvodnju multienzimskoga pripravka za hranidbu životinja. U razdoblju 1953-66. izgrađeno je novo postrojenje za proizvodnju vitamina $C$ te za fermentaciju i izolaciju oksitetraciklina. Godine 1957. u PLIVU je pozvan dr. Gavro Taburašev kako bi započeo istraživanja fermentativnih procesa, a cilj je bio izrada postupka za proizvodnju antibiotika oksitetraciklina i drugih antibiotika te skupine, što je uspješno dovršio 1959. Iste godine započela je i proizvodnja vitamina B6. U 1970-ima, kao odgovor na izazov pronalaska antibiotika poboljšanih svojstava spram eritromicina A i klaritromicina, zaposlenici PLIVINA Istraživačkoga instituta (Slobodan Đokić, Gabrijela Kobrehel, Zrinka Tamburašev i Gorjana Radobolja-Lazarevski) 1979-81. sintetizirali su novi makrolidni antibiotik, koji je predstavljao prvoga člana nove skupine makrolidnih antibiotika, azalida. PLIVA je azitromicin stavila na tržište 1988. pod robnom markom Sumamed, a Pfizer 1991. pod nazivom Zithromax. Najveći je uspjeh PLIVA postigla upravo otkrićem makrolidnoga antibiotika, azitromicina. Osim azitromicina, 1976-86. uvedena su u proizvodnju 132 nova lijeka, od kojih 58 na osnovi vlastite farmaceutske sirovine ili recepture. PLIVA je svoje poslovanje proširila pripajanjem više farmaceutskih kompanija u Poljskoj, Češkoj, Njemačkoj, Velikoj Britaniji, SAD-u i dr. Od 2005. PLIVA svoje istraživačke aktivnosti usmjerava ponajprije na razvoj generičkih lijekova. Godine 2006. većinski vlasnik PLIVE postala je američka kompanija Barr Pharmaceuticals, a od 2008. PLIVA je u sastavu izraelske Teva grupe. 
se rabila za dobivanje novih biološki aktivnih tvari, za kloniranje gena u mikroorganizmima (streptomiceti, E. coli, Bacillus sp.), u pronalaženju novih biosintetskih puteva s pomoću metaboličkoga inženjerstva (mikroorganizmi Erwinia, Aureobacterium) i za konstrukciju plazmidnih vektora za industrijski važne sojeve bakterija (Delić 1993: 85; Hranueli 1984: 27). Tehnologije koje su u svijetu bile razvijene na modelima bakterija, a s kojima su istraživači PLIVE imali iskustva zbog proizvodnje antibiotika u streptomiceta (Đokić 1986: 1881, 1987: 1006, 1988: 152), bile su čvrsta osnova za razvoj i primjenu novih tehnologija genetičkoga inženjerstva (Mutak, 2016: 359). V. Delić se u PLIVINU Istraživačkom institutu bavio konstrukcijom, kloniranjem i ekspresijom gena u prokariotskim organizmima metodama rekombinantne DNA, a objavio je čak pet patenata ${ }^{9}$. Pridonio je otkrivanju metode kooperativne biosinteze za analizu redoslijeda blokova u biosintetskim putevima mikroorganizama, pronašao je optimalne uvjete mutageneze nitrozogvanidinom u bakterija roda Streptomyces i Gaffkya, proveo izolaciju i karakterizaciju regulatornih mutanata u biosintetskim putevima za histidin i izoleucin u mikroorganizama te otkrio nove neopisane plazmide u roda Erwinia. Utvrđeno je da su genomi nekih prokariota vrlo stabilni za razliku od genoma streptomiceta koji pokazuju znatnu nestabilnost. Tada je već više od 20 godina farmaceutska industrija selektirala proizvodne sojeve zbog većega prinosa antibiotika, ali su ti »hiperproducenti« bili često genetički nestabilni. D. Hranueli bio je voditelj znanstvenoga projekta Struktura, složenost $i$ stabilnost genoma streptomiceta (Ministarstvo znanosti, obrazovanja i športa /MZOŠ/, 1991-95), a suradnice su bile Marija Alačević i Margareta Vešligaj (Vešligaj 1981: 986). Temeljni ciljevi ovoga projekta bili su: bolje razumijevanje molekularnih osnova genetičke nestabilnosti $\mathrm{u}$ »hiperproducenata $\mathrm{i}$ uporaba tih informacija u pripravi stabilnih derivata s povećanim proizvodnim potencijalom, analiza genetičkih preraspodjela dijelova DNA (npr. delecija, duplikacija i amplifikacija) koje se pojavljuju u nestabilnih izolata npr. soja $S$. rimosus R6, karakterizacija dodatnih genetičkih elemenata (gigantskoga linearnog plazmida i provirusa) i ispitivanje njihove uloge u biosintezi antibiotika i genetičkoj nestabilnosti, te konstrukcija stabilnih vektora. U isto vrijeme, J. Pigac bila je glavna istraživačica na projektu Ekspresija gena u micelijskim mikroorganizmima, a suradnici su joj bili Radovan Valinger, Z. Toman, Margareta Vešligaj, Silvija Meštrić, Šumski Šimaga i Štefica Šumiga-Kobrehel, te je imala razvijenu suradnju sa Sveučilištem u Glasgowu. Pigac se u istraživanjima na ovom projektu koristila spoznajama i rezultatima dugogodišnjih proučavanja streptomiceta i aspergila u PLIVINIM laboratorijima, kao i najnovijim dostignućima metodologija i tehnika za proučavanje ekspresije gena u ovim mikroorganizmima. Prvi je put opisala i

9 Npr. patent US5252481A - Mutant of bacterium Clostridium histolyticum, a process for the obtaining thereof, and its use in the production of clostripain-free collagenase iz 1991 (izumitelji: Milan Holjevac, Ivan Udovičić, Sonja Čižmek, Vlasta Sojak-Derkos, Stjepan Gamulin, V. Delić), te patent DE3212380A1 Process for obtaining purines by fermentation iz 1981. (izumitelji: V. Sojak-Derkos i V. Delić). 
uvela brzu i pouzdanu metodu za transformaciju streptomiceta elektroporacijom, što je omogućilo uvođenje različitih vektora kao i ugrađivanje i ekspresiju VHb-gena (hemoglobin gen iz bakterije Vitreoscilla) u kromosom soja S. rimosus R6. Upravo ovakvo predznanje PLIVINIH stručnjaka omogućilo je prikupljanje potrebnih informacija za pripravu stabilnih proizvodnih sojeva u farmaceutskoj industriji s pomoću genetičkoga inženjerstva. U PLIVINU Istraživačkom institutu također su se bavili kloniranjem i ekspresijom gena različitoga podrijetla radi proizvodnje proteina i razvoj potencijalnih sojeva za proizvodnju homolognih i heterolognih proteina, npr. ispitivala se ekspresija gena za primarne (glukoamilaza) i sekundarne metabolite (poliketidni antibiotik, oksitetraciklin - OTC) u micelijskim mikroorganizmima. Napravljeni su prvi pokušaji ekspresije heterolognih gena u svrhu povećanja prinosa OTC-a, te ekspresija gena za humani inzulin. Kombinacijom kemijske i biokemijske metode sintetizirao se gen za humani proinzulin, koji je bio pod kontrolom regulatornih sljedova glukoamilaznoga gena u micelijskom organizmu.

PLIVINA istraživanja na biotehnologiji sekundarnih metabolita završavaju 1990-ih godina - projekt antibiotika mupirocina zadnji je u nizu. Nova era nastupa uvođenjem rekombinantnih tehnologija temeljenih na kulturama stanica i mikroorganizmima. PLIVA uspješno razvija ekvivalentne biološke proizvode, čime dokazuje svoju ekspertizu u području molekularne biologije, formulacija, gotovih oblika, proizvodnje, te pokazuje potencijal za uspješno sudjelovanje na svjetskom tržištu bioloških lijekova. Radilo se na dvama biološkim lijekovima: eritropoetinu (EPO) i faktoru stimulacije rasta granulocita (G-CSF), na kojima je PLIVA surađivala s poduzećima Barr Pharmaceuticals i Mayne Pharma. Hrvatska Agencija za lijekove i medicinske proizvode (HALMED) dala je 2005. odobrenje PLIVI za stavljanje u promet biosličnoga eritropoetina - ta registracija EPO-a ujedno je predstavljala prvu europsku registraciju generičke inačice originalnoga biološkog lijeka koji je proizvela tvrtka Johnson \& Johnson. Radi se o lijeku koji stimulira proizvodnju eritrocita u bolesnika s kroničnim bubrežnim zatajenjem na dijalizi i bolesnika koji primaju kemoterapiju. Od 2005. PLIVA svoje istraživačke aktivnosti usmjerava ponajprije na razvoj generičkih lijekova. U listopadu 2006. većinski vlasnik PLIVE postala je američka kompanija Barr Pharmaceuticals, koju je 2008. kupila izraelska kompanija Teva Pharmaceuticals, pa se PLIVA od 2008. nalazi u sastavu Teva grupe. PLIVA 2009. prodaje biotehnološko poslovanje američkoj kompaniji Hospira te pogon Hrvatski Leskovac Hrvatskom zavodu za transfuzijsku medicinu.

Danas hrvatska farmaceutska industrija koristi biotehnologiju i tehnologije genetičkoga inženjerstva $u$ istraživanju i proizvodnji farmaceutskih proizvoda. $U$ proizvodnim pogonima tvornice Hospira Zagreb d.o.o. proizvodi se lijek filgrastim $\left(\right.$ Nivestim $\left.^{\circledR}\right)$, rekombinantni ljudski faktor stimulacije rasta granulocita (G-CSF), i to je zasad jedini odobreni bioslični lijek koji se proizvodi u Hrvatskoj. Lijek se prven- 
stveno koristi kako bi se smanjila učestalost i trajanje kronične neutropenije i pridruženih komplikacija. Filgrastim je rekombinantni terapijski protein koji se sastoji od 175 aminokiselina, molekulske mase 18800 Da. Sličan je humanom proteinu G-CSF, koji je za razliku od filgrastima glikoziliran i sadržava dodatnu aminokiselinu na N-kraju proteina (metionin). U proizvodnji se koristi plazmidni vektor konstruiran tehnikama genetičkoga inženjerstva, a proizvodnja proteina odvija se u stanicama bakterije $E$. coli. Filgrastim se proizvodi submerznim uzgojem $E$. coli u više faza pri optimalnim fiziološkim uvjetima. Proces proizvodnje podijeljen je u četiri faze, koje čine uzgoj cjepiva I u Erlenmeyer tikvicama, zatim uzgoj cjepiva II za biosintezu u biorektoru manjega volumena, biosinteza u bioreaktoru volumena 301 te faze separacije i pročišćavanja ${ }^{10}$. Budući da se proizvod nalazi u obliku inkluzijskih tijela, potrebne su višestruke separacije, razmuljivanje, homogenizacija i centrifugiranje, prvo same dobivene biomase, a zatim inkluzijskih tijela.

Nove tehnike u genetičkom i biokemijskom inženjerstvu omogućile su razvoj niza novih procesa koji se prije iz tehničkih razloga nisu mogli ostvariti. Različite istraživačke skupine, većinom okupljene oko sveučilišta (Farmaceutsko-biokemijski fakultet, Zagreb; PBF, Zagreb; Medicinski fakultet, Rijeka; Medicinski fakultet, Zagreb; PMF, Zagreb; Fakultet kemijskog inženjerstva i tehnologije, Zagreb; PMF, Split; Medicinski fakultet, Osijek; Centar za istraživanje i prijenos znanja u biotehnologiji, Sveučilište u Zagrebu), instituta (Mediteranski institut za istraživanje života, IRB), Hrvatskoga zavoda za javno zdravstvo i poduzeća (Fidelta d.o.o. za istraživanje i razvoj; BICRO BIOCentar d.o.o." ${ }^{11}$, Genera istraživanja d.o.o.; Hospira Zagreb d.o.o.), rabe tehnologiju rekombinantne DNA u svojim istraživanjima i u dijagnostici. Prema Zakonu o genetski modificiranim organizmima, sve institucije u Hrvatskoj koje rade s GM-organizmima upisane su u odgovarajući upisnik koji vodi nadležno ministarstvo. U ovaj upisnik je do 2019. upisano 19 institucija s ukupno 55 prijavljenih zatvorenih sustava za rad s GMO-om (laboratorija/ustrojbenih jedinica), većinom registriranih za najnižu razinu opasnosti 1 , dok je za razinu opasnosti 2 registrirano 11 laboratorija, $\mathrm{s}$ time da je za obje razine rizik za ograničenu uporabu GMO-a zanemariv ili malen.

10 Vrbić, Antonija (2011), Biotehnološka proizvodnja terapijskog proteina filgrastima (diplomski rad), PBF, Zagreb.

11 BICRO BIOCentar, hrvatski istraživački i razvojni centar, nacionalni resurs koji razvija mrežu zainteresiranih partnera u području biotehnologije. Otvoren je 2015. u suradnji Hrvatskom agencijom za malo gospodarstvo, inovacije i investicije (HAMAG-BICRO), Ministarstvom znanosti i obrazovanja, Sveučilištem u Zagrebu i Gradom Zagrebom. Zamišljen je kao inkubacijski centar s laboratorijima i uredskim prostorima ukupne površine oko $4500 \mathrm{~m}^{2}$ kako bi, na znanju utemeljenim poduzećima u nastanku, pružio potrebne uvjete za obavljanje njihove djelatnosti u području biotehnologije, a sve u svrhu spajanja znanstvenih skupina i industrije radi komercijalizacije tehnologije. 


\section{2. Genetičko inženjerstvo u hrvatskoj znanosti}

Kad je Zakonom od 1902. podignut gospodarski odjel križevačkoga učilišta na rang višega učilišta, u Križevcima se stvara brojni znanstveni kadar, a mnogi bivši studenti postat će poznati znanstvenici izvan Hrvatske. Najpoznatiji među njima je Milislav Demerec, hrvatsko-američki genetičar, koji je kraće vrijeme radio u Križevcima, ali 1919. odlazi u SAD te svojim radom u inozemstvu postaje jedan od najvažnijih genetičara svojega vremena (Šerman 2013: 123). Od 1940. Demerec traga za organizmom koji bi imao vrlo mnogo potomaka, pa u Cold Spring Harbor poziva Maxa Delbrücka i Salvadora Luriju, te tako $u$ laboratorije na velika vrata ulaze istraživanja bakterija $i$ bakterijskih virusa - bakteriofaga (Šerman 2013: 115). Rezistencija bakterije E. coli na bakterijske viruse 1945. naznačuje prekretnicu u Demerčevu radu i radu njegova laboratorija (Demerec 1933: 368, 1948: 63). Godine 1950. u Cold Spring Harbor dolazi i Alfred Hershey koji započinje svoje poznate eksperimente s bakteriofagima. Hershey će za ta istraživanja 1969. dobiti Nobelovu nagradu za fiziologiju ili medicinu, koju će podijeliti s M. Delbrückom i S. Lurijom. Od 1941. u Cold Spring Harboru i Barbara McClintock započinje svoja istraživanja o nestabilnosti gena i kromosoma kukuruza, te radi na otkriću transpozona, za koja će 1983. dobiti Nobelovu nagradu za fiziologiju ili medicinu (Šerman 2013: 115). Od 1950. Demerec se posvema posvećuje genetici mikroorganizama i sa svojim suradnicima utemeljuje bakterijsku genetiku, iz koje izrasta suvremena molekularna biologija i današnja molekularna genetika (Demerec 1963: 1519). Potaknut otkrićem transdukcije u bakterije Salmonella typhimurium Nortona Zindera i Joshue Lederberga 1952., Demerec i cijeli njegov tim započinju analizu gena koji kontroliraju sintezu raznih aminokiselina u bakterija. Ispitivanjem funkcionalne organizacije bakterijskoga kružnoga kromosoma otkriva fenomen bliske vezanosti gena čiji proteinski proizvodi - enzimi - omogućuju ostvarenje sličnih funkcija. Njegova otkrića bila su ključna za suvremeno razumijevanje funkcije gena i razvoj genetičkoga inženjerstva. Nastavivši suradnju sa znanstvenicima u Hrvatskoj, Stjepanom Jurićem, Aloisom Tavčarom i Albertom Ogrizekom, pomagao je još od 1920-ih razvoj biometrike i oplemenjivanja bilja na Agronomskom fakultetu u Zagrebu.

\section{2. 1. Genetičko inženjerstvo na Prehrambeno-biotehnološkom fakultetu - razvoj genetike industrijskih mikroorganizama}

Pod vodstvom profesorice Vere Johanides, u Laboratoriju za industrijsku mikrobiologiju Tehnološkoga fakulteta u Zagrebu (danas PBF), krajem 1970-ih prvi se put u Hrvatskoj počinje razvijati genetika industrijskih mikroorganizama (Šušković 2019: 438). Od 1979. pod vodstvom je M. Alačević. ${ }^{12}$ Godine 1980. naziv je promijenjen u Labo-

12 Alačević, Marija (Makarska, 19. IV. 1929 - Zagreb, 25. II. 2015), mikrobiološka inženjerka. Stručnjakinja za mikrobiološku genetiku u prehrambenoj i kemijskoj industriji. U Zagrebu je na PMF-u 
ratorij za biologiju i genetiku mikroorganizama, u kojem su nastavljena istraživanja oplemenjivanja industrijskih mikroorganizama primjenom klasičnih genetičkih metoda i metoda rDNA, posebice bakterija roda Streptomyces koje se koriste u proizvodnji antibiotika, kao i proučavanje molekularnih mehanizama mutageneze i popravka DNA. Prof. Alačević bavila se genetikom industrijskih organizama, rekombinacijama u streptomiceta, biosintezom histidina u vrsti Streptomyces rimosus, rekombinacijama među sojevima te vrste te redoslijedom genetičkih markera na njihovu kromosomu i njihovim genetičkim mapiranjem. Radeći na organizmima koji proizvode antibiotike, bila je dugogodišnja suradnica farmaceutskoga poduzeća PLIVE. Sa svjetski poznatim genetičarem Miroslavom Radman, Alačević je 1978. iznijela zamisao o prvom Centru za molekularnu genetiku, kao međunarodnom centru koji će pod pokroviteljstvom Ujedinjenih naroda djelovati u Splitu, ali ta zamisao tada nije zaživjela. U preinačenu obliku sredinom 2000-ih ostvarena je kao splitski Mediteranski institut za istraživanje života (MedILS) (Rudež 2013: 87).

Od 1980-ih na PBF-u djelovao je profesor Zoran Zgaga, biotehnološki inženjer, stručnjak za molekularnu biotehnologiju i utemeljitelj istraživanja genetike kvasaca u Hrvatskoj. Područja su njegova znanstvenoga i stručnoga interesa bila molekularna biotehnologija i genetičko inženjerstvo u biotehnologiji, naročito istraživanja u kvascima. Istraživao je učinkovitost homologne rekombinacije koristeći integraciju plazmida (jednolančanoga i dvolančanoga) u kromosom kvasca. Predavao je kolegije Molekularna genetika, Genetičko inženjerstvo, Izolacija, konstrukcija i održavanje proizvodnog soja te Genetika eukariota. Također se bavio proučavanjem palindroma u genomima i mehanizmima zamjene gena u kvasca. Jedan je od utemeljitelja Hrvatske udruge genetičkih inženjera (HUGI) ${ }^{13}$ neprofitne udruge znanstvenika i stručnjaka Hrvatske koji u svojoj znanstvenoj i stručnoj praksi primjenjuju genetičko inženjerstvo. Udruga je osnovana 2001. u Zagrebu, a najvažniji motiv za osnivanje bilo je stručno i objektivno izvještavanje javnosti sredstvima javnoga priopćavanja o temeljnim spoznajama i primjeni genetičkoga inženjerstva. Članovi Udruge nastoje unaprijediti razvoj genetičkog inženjerstva u Republici Hrvatskoj, stručno i objektivno predstaviti genetičko inženjerstvo najširoj javnosti, sudjelovati u izradbi pravil-

1954. diplomirala biologiju, a na Tehnološkome fakultetu 1965. doktorirala disertacijom Interspecijske rekombinacije vrsta roda Streptomyces (mentorica V. Johanides). Radila je 1956-79. na Kemijsko-tehnološkome te 1956-94. na Prehrambeno-tehnološkom odjelu Tehnološkoga fakulteta (danas PMF), od 1978. kao redovita profesorica. Predavala je kolegije iz genetike mikroorganizama, za što se usavršavala u Rimu 1961. i 1964. Bila je predstojnica Zavoda za biokemijsko inženjerstvo 1990-95. te voditeljica Laboratorija za biologiju i genetiku mikroorganizama 1979-94. Umirovljena je 1994. Autorica je mnogobrojnih radova te je objavljivala u časopisima Nature (1963), Mikrobiologija (1965), Fournal of Genetical Microbiology (1973), Mutation Research (1991) i dr. Suosnivačica je Hrvatskoga genetičkog društva (1978). Dobitnica je Nagrade »Ruđer Bošković« 1981. Od 1997. je professor emeritus Sveučilišta u Zagrebu. Podatci preuzeti s https://tehnika.lzmk.hr/alacevic-marija/ (pristupljeno 30. VI. 2020).

13 Podatci preuzeti s http://www.hugi.hr/ (pristupljeno 30. VI. 2020). 
nika i zakona o genetičkom inženjerstvu, te nastavnoga plana i programa iz područja biologije i genetike, sudjelovati u zaštiti ljudskoga zdravlja, biološke raznolikosti i okoliša, te znanstveno i stručno surađivati s pojedincima, udrugama i institucijama. Od 2011. Udruga dodjeljuje nagradu, koja nosi ime prof. Zgage, za najbolji diplomski rad u kojem se primjenjuju metode genetičkoga inženjerstva.

\section{2. 2. Genetičko inženjerstvo na Institutu Ruđer Bošković - razvoj i utemeljenje metoda}

U Hrvatskoj, samo tri godine nakon otkrića strukture DNA (1953), u IRB-u formirala se mala jezgra istraživača (Branimir Miletić, Željko Kućan, Dina Keglević) koja - u skladu s općim tendencijama istraživanja Instituta u tom razdoblju - počinje ispitivati djelovanje zračenja na DNA. Rad na području molekularne biologije uključivalo je istraživanje radiobioloških učinaka na razini stanice metodama biofizike, biokemije, mikrobiologije, citologije i genetike. Započeta su istraživanja virusa, bakterija i životinjskih stanica u kulturi. Već na početku rada otkriveno je da gama-zračenje razgrađuje DNA u bakterijama i mnogo godina laboratorij je zadržao ugledno mjesto u svjetskim okvirima na istraživanju te pojave. $U$ usporednim istraživanjima otkriveno je da gama-zračenje prouzrokuje razgradnju dijela RNA ozračenih bakterija. Fotorestauracija (oporavak pod utjecajem svjetlosti), kao aktualna problematika u to doba, također se istraživala u bakterijskim sustavima.

Uspješan razvoj znanstvenih istraživanja u 1960-ima i 1970-ima vrlo je brzo obogaćen suradnjama IRB-a s farmaceutskom i kemijskom industrijom. Izravna suradnja Instituta s PLIVOM započela je 1967. ugovorom Tetraciklinski antibiotici. Suradnja se proširuje sklapanjem još nekoliko manjih ugovora, a 1970. sklapa se velik ugovor Peptidi i proteini, koji je angažirao gotovo cijeli Odjel organske kemije i biokemije. Tijekom godina suradnja se usmjeravala prema specifičnim temama (beta-laktamski antibiotici, biološki aktivni peptidi, enzimi), koje obuhvaćaju zasebni ugovori. Neosporno, suradnja Instituta i PLIVE bila je tada iznimno uspješna: u tih deset godina iz devet ugovora proizašlo je 20 patenata, a desetak suradnika PLIVE specijaliziralo se u Institutu i steklo zvanje magistra ili doktora znanosti. Gledajući s kadrovske strane, broj zaposlenika u znanstvenom sektoru u Institutu u razdoblju 1971-79. iznosio je oko 500. Zanimljiv podatak jest i srednja dob istraživača: 1979. ona je iznosila 37,5 godina. Mladi su ljudi, dakle, u Institut dolazili, a suradnici s višim akademskim zvanjima odlazili iz Instituta. Iz Instituta je do tada na fakultete prešlo više od 100 istraživača, a u industriju oko 120 istraživača. Iskustva stečena radom u molekularnoj biologiji i genetici usmjerila su istraživače na područje genetičkoga inženjerstva, za primjenu koja su bili zainteresirani i zdravstvo i privreda. Iz inozemnih znanstvenih institucija dobiveni su čisti, srođeni sojevi laboratorijskih životinja i standardne kulture životinjskih stanica, te bakterija i virusa. Tako je 1970-ih u Insti- 
tutu formiran vlastiti uzgoj laboratorijskih životinja i banka staničnih kultura, što je bio pionirski pothvat u našoj zemlji.

Razvoj metoda i utemeljenje genetičkoga inženjerstva u Hrvatskoj započeo je 1970-ih godina, kada je Republička zajednica za znanstveni rad na prijedlog IRB-a i PLIVE u okviru zajedničkoga ugovora počela financirati izrazito prioritetno istraživanje konstrukcije stabilnih bifunkcionalnih vektora (dvojnih plazmida) za prijenos gena između Streptomyces spp., važnih industrijskih proizvođača antibiotika, i bakterije $E$. coli pod naslovom »Primjena genetičkog inženjerstva u biotehnologiji: konstrukcija plazmida za kloniranje gena kod streptomiceta, industrijskih proizvođača antibiotika«. Naime, Republički fond postao je glavni financijer Instituta u razdoblju 1971-75., kada je nastupilo doba samoupravljanja uz »ourizaciju« (Rudež 2017: 11). Naime, Institut se 1974. počeo organizirati u OOUR-e (Osnovne organizacije udruženoga rada). Osnivanjem SIZ-ova (samoupravnih interesnih zajednica) 1976., oni postaju glavni izvor institutskih sredstava, a ukidaju se 1990. osnivanjem Ministarstva znanosti tehnologije i informatike Republike Hrvatske. Molekularno-genetička istraživanja streptomiceta doživjela su uzlet tih godina, međutim još uvijek je nedostajalo prikladnih vektora za kloniranje gena. Postignuti su se rezultati uključivali u opći fond znanja na tom području, što je urodilo porastom društvene uloge znanstvenih djelatnika i odgovarajućim domaćim i međunarodnim priznanjima. Kronologiju zbivanja povezanih s temom genetičkoga inženjerstva od početka 1970-ih nemoguće je zamisliti bez udjela profesora Ž. Kućana ${ }^{14}$, u skladu s činjenicom što mu je neosporno priznat status jednoga od vodećih hrvatskih biokemičara. Glavno područje interesa mu je biokemija nu-

14 Kućan, Želiko (Zagreb, 24. V. 1934), biokemičar. Završivši gimnaziju u Zagrebu 1953. upisao je biokemiju na Kemijskom odjelu PMF-a. Tijekom studija dobio je stipendiju IRB-a. Diplomirao je 1958. (Pokušaj izolacije aktivne tvari iz Monilia laxa, mentor K. Balenović), a doktorat kemijskih znanosti postigao 1964 (Studij poremećaja biosinteze deoksiribonukleinske kiseline nakon X-zračenja, mentor B. Miletić). Od 1958. do 1983. radio je u IRB-u, isprva u Radiobiološkom odjelu, a zatim u Odjelu Organske kemije i biokemije. Bio je pročelnik Odjela organske kemije i biokemije 1972-76., osnivač i voditelj Laboratorija za biosintezu, a nekoliko je puta bio biran za tajnika Znanstvenoga vijeća Instituta. Godine 1972. bio je izabran za docenta, a odmah zatim i za izvanrednoga profesora biokemije u Zavodu za organsku kemiju i biokemiju PMF-a. Godine 1983. posve prelazi na Fakultet kao redoviti profesor biokemije. Od 1985. do 1988. bio je pročelnik Kemijskoga odjela, od 1988. predstojnik Zavoda za organsku kemiju i biokemiju, a od šk. god. 1990/91. do 1993/94. dekan Fakulteta. Od 1995. do 1999. bio je predstojnik novoosnovanoga Zavoda za biokemiju, a do 2000. i prodekan za ulaganja PMF-a. Više od šest godina je proveo u inozemnim znanstvenim institucijama. Od 1961. do 1963. boravio je u laboratoriju nobelovca Fritza Lipmanna u Rockefellerovu institutu u New Yorku, gdje je započeo istraživanja biosinteze proteina. Od 1969. do 1972. radio je kao gostujući istraživač u laboratoriju R. W. Chambersa na Odsjeku za biokemiju Sveučilišta u New Yorku te bio i gostujući profesor biokemije u šk. god. 1977/78. i 1978/79. Bio je predsjednik Hrvatskoga biofizičkog društva, u dva navrata predsjednik Hrvatskoga biokemijskog društva, dugogodišnji član redakcija časopisa Croatica Chemica Acta i Periodicum Biologorum, organizator međunarodnih i domaćih ljetnih škola, kongresa i sl. Redoviti član HAZU od 1991. Dobitnik je Republičke nagrade za znanstveni rad »Ruđer Bošković« (1991). Nositelj je Reda Danice hrvatske. Podatci preuzeti s https://dizbi.hazu.hr/a/?pc=i\&id=50250 (pristupljeno 16. VI. 2020). 
kleinskih kiselina i njihova uloga u biosintezi proteina. Budući da se radi o području biokemije, koje se naziva i molekularnom biologijom, kemičari ga često smatraju čistim biologom, a biolozi čistim kemičarom. Nukleinske kiseline - čija struktura dvostruke zavojnice omogućuje svoju vlastitu replikaciju, dakle nasljeđivanje genetičke informacije, te proteini - kao osnovni nosioci života i biokemijskih reakcija činili su važna područja istraživanja Instituta, koja su uglavnom biokemijskoga karaktera, tj. polazila su od izolacije makromolekule iz prirodnoga materijala s konačnom svrhom da se ispitaju njene reakcije pod biološkim uvjetima. Već 1975. u OOUR-u Organske kemije i biokemije (OKB, slika 3) istraživali su se izolacija i određivanje struktura polimera iz stanične ovojnice bakterija, mehanizam transformacije stanica onkogenim virusima, katabolizam pirimidina u bakterija, interakcija specifičnih enzima sa tRNA (transfer RNA), izolacija i karakterizacija enzi-

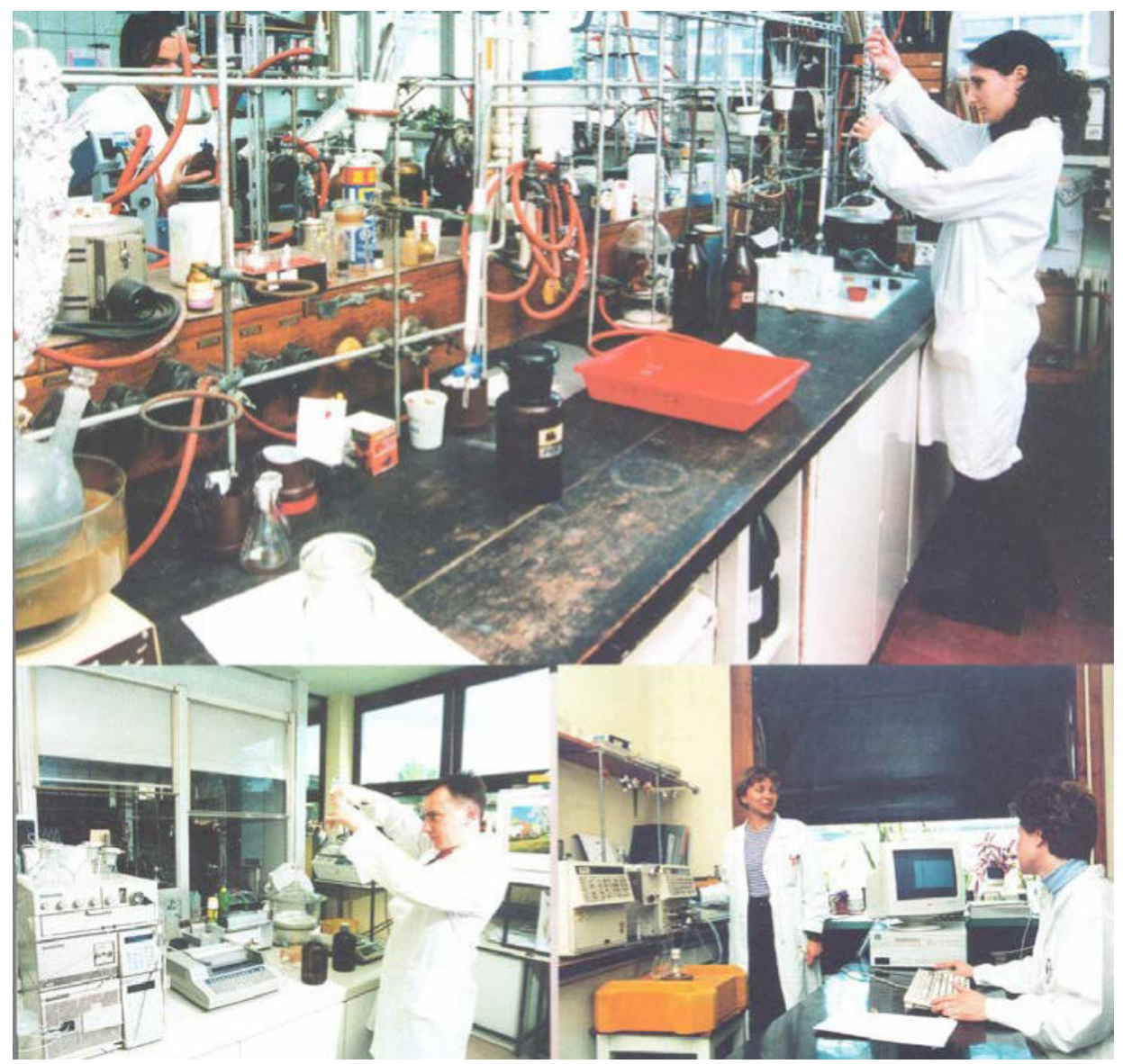

Slika 3. Institut Ruđer Bošković - OOUR Organske kemije i biokemije (OKB). Preuzeto iz Spomenice Instituta Ruđer Bošković uz 30. godinu osnutka (1950.-1980.). 
ma vezanih uz metabolizam nukleinskih kiselina, proteina, peptida i njihovih prekursora. Također, radilo se na dva projekta s PLIVOM: Ispitivanje djelovanja antibiotika u ekstraktima bakterija i lzolacija $i$ karakterizacija nekih hidrolitickih enzima (voditelj Ž. Kućan). Godine 1976. u OOUR-u OKB-a radila su 32 istraživača, 14 asistenata postdiplomanada te 15 tehničkih suradnika. Iste je godine profesor Kućan osnovao je Laboratorij za biosintezu IRB-a unutar OOUR-a OKB-a, u kojem su neko vrijeme proveli istraživači Vera Gamulin, Ira Kućan, a poslije Miroslav Plohl, Đurdica Ugarković i Ivana Weygand-Durašević, kasnije docentica i profesorica na PMF-u. Upravo u Laboratoriju za biosintezu IRB-a utemeljile su se metode genetičkoga inženjerstva u Hrvatskoj, a znanje se razmjenjivalo s PLIVOM i s nekoliko godina kasnije osnovanim laboratorijem, danas zvanoga Laboratorij za biologiju i genetiku mikroorganizama, koji je na PBF-u 1980. osnovala M. Alačević. U 1980-ima naglo je poraslo specijalističko poznavanje metodologije i aktualne problematike znanstvenoga rada, što je unaprijedilo istraživačke mogućnosti i rezultate. Već 1976. u Laboratoriju za biosintezu započinju istraživanja procesa biosinteze proteina, izolacija i karakterizacija enzirna vezanih uz funkciju tRNA te analiza interakcije proteina s tRNA. Ubrzo, u Laboratoriju za biosintezu IRB-a metodologijom rekombinantne DNA isprva se istraživala primarna struktura, genomska organizacija te regulacija ekspresije gena kod E. coli, kvasaca i streptomiceta. Istraživanja organizacije, strukture i načina ekspresije gena za tRNA iz bakterije $S$. rimosus rezultirala su određivanjem primarne strukture nekoliko gena za tRNA. Kasnije su se bavili analizom promotorskih i terminatorskih regija gena, proučavala se fotoreaktivnost neuobičajenih nukleozida, organizacija genoma kukca brašnara, te odnos strukture i funkcije nukleinskih kiselina na modelu tRNA iz kvasca, a neka od tih istraživanja odvijala su se u suradnji s Kemijskim odsjekom PMF-a u Zagrebu. U ranim 1980-im godinama u Laboratoriju su uspostavljene brojne metode genetičkog inženjerstva, kao što su: izolacija i detekcija plazmida u E. coli i Streptomyces lividans, transformacija DNA, izolacija čiste DNA plazmida ultracentrifugiranjem u gradijentu cezijeva klorida i etidijeva bromida, elektroforeza na gelu agaroze i poliakrilamida, obilježavanje krajeva DNA i tRNA radioaktivnim izotopom fosfora ${ }^{32} \mathrm{P}$, metoda prijenosa kromosomske i plazmidne DNA s agaroznog gela na nitrozelulozne filtre kao i hibridizacija DNA. Specifičnim nukleolitičkim cijepanjem i zatim enzimskim spajanjem plazmida pBR322 i pIJ350 dobiven je željeni bifunkcionalni vektor, tj. plazmid pogodan za ugradnju stranih gena koji se dobro umnožava u dvije vrste bakterija. U to istraživanje bile su uključene istraživačke grupe okupljene oko prof. Alačević (Alačević 1973: 173) s PBF-a, PLIVINA Istraživačkoga instituta, prof. Kućana s PMF-a i Vere Gamulin iz IRB-a. Ključni korak u realizaciji načinile su V. Gamulin i J. Pigac (slika 4) koje su 1985. nakon dugotrajne selekcije uspješno konstruirale vektor pZG1 te potom i nekoliko drugih bifunkcionalnih plazmidnih vektora za prijenos gena između Streptomyces spp. i bakterije E. coli (Durajlija 1991: 317). Plazmid pZG1 bio je prvi 
rekombinantni ekspresijski vektor konstruiran u Hrvatskoj i to je otkriće objavljeno 1988. godine (Pigac 1988: 222). Potom se istraživala strukturna nestabilnost bifunkcionalnoga plazmidnog vektora pZG1 u sojevima Streptomyces lividans i Streptomyces rimosus, te se nastavilo s konstrukcijom novih bifunkcionalnih vektora s potencijalno stabilnijim svojstvima. Kasnije konstruirani plazmidi pZG5 i pZG6 uspješno su korišteni za unos nekoliko homolognih gena za tRNA u S. rimosus. V. Gamulin neosporno je bila jedna od ključnih osoba u molekularnoj biologiji u Hrvatskoj, koja je prva prepoznala važnost tehnologije rekombinantne DNA. Početkom 1980-ih odlazi na Sveučilište Yale, u laboratorij profesora Dietera Sölla, gdje je kao poslijedoktorski student radila na karakterizaciji gena za tRNA i na proučavanju reakcije aminoaciliranja tRNA. Dvogodišnji boravak na Sveučilištu Yale u velikoj je mjeri označio njezinu znanstvenu karijeru, tijekom koje je cijelo vrijeme proučavala strukturu različitih gena i njihove evolucijske odnose. Po povratku u IRB glavni znanstveni interes bio joj je proučavanje gena za rRNA (ribosomska RNA) i tRNA u industrijski važnim bakterijama roda Streptomyces, te konstrukcija bifunkcionalnih ekspresijskih vektora. Kasnije, tijekom 1990-ih godina, njezin znanstveni interes okrenuo se više prema molekularnoj evoluciji morskih spužava (Četković 2007: 332). Krajem 2004., zahvaljujući njezinom višegodišnjem zalaganju i sredstvima MZOŠ-a za nabavku krupne opreme, u Zavodu za molekularnu genetiku IRB-a uspostavljen je uređaj za automatsko sekvenciranje DNA (DNA-sekvenator), čime se utemeljio servis za očitavanje slijeda nukleotida molekula DNA dostupan svim znanstvenicima - prva servisna djelatnost toga tipa

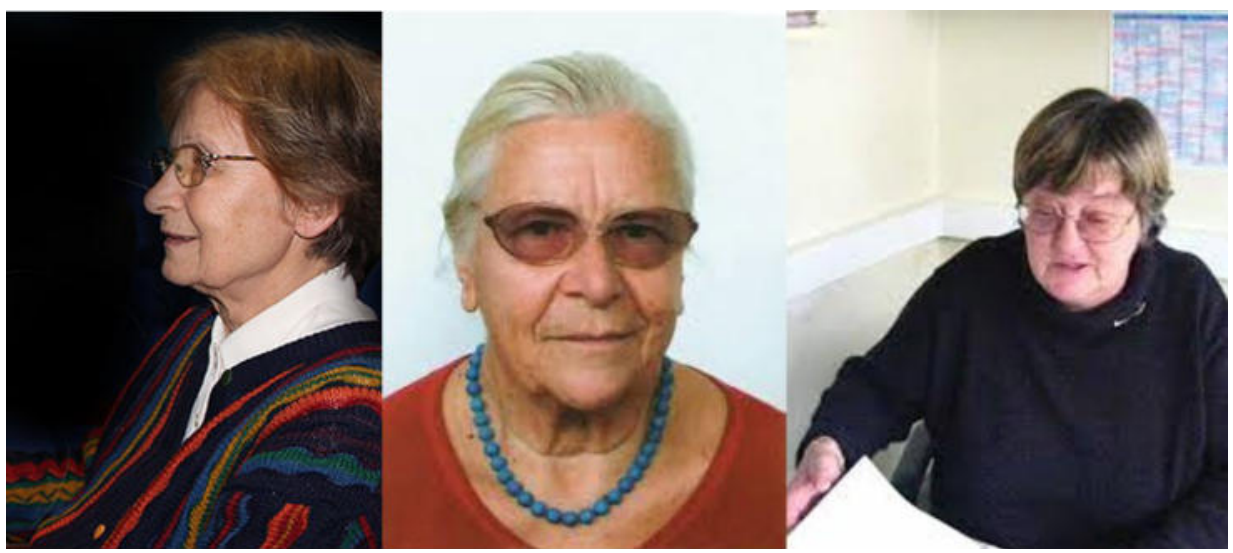

Slika 4. Znanstvenice dr. sc. Jasenka Pigac (PLIVA), prof. dr. sc. Marija Alačević (PBF) i dr. sc. Vera Gamulin (IRB) i članovi njihovih istraživačkih skupina zaslužni su za uspješno provođenje izrazito prioritetnoga istraživanja konstrukcije stabilnih bifunkcionalnih vektora (dvojnih plazmida) za prijenos gena između Streptomyces spp., važnih industrijskih proizvođača antibiotika, i bakterije $E$. coli, pod naslovom Primjena genetičkog inženjerstva u biotehnologiji: konstrukcija plazmida za kloniranje gena kod streptomiceta, industrijskih proizvođača antibiotika, koje je rezultiralo konstrukcijom prvoga rekombinantnoga vektora u Hrvatskoj (pZG1). 


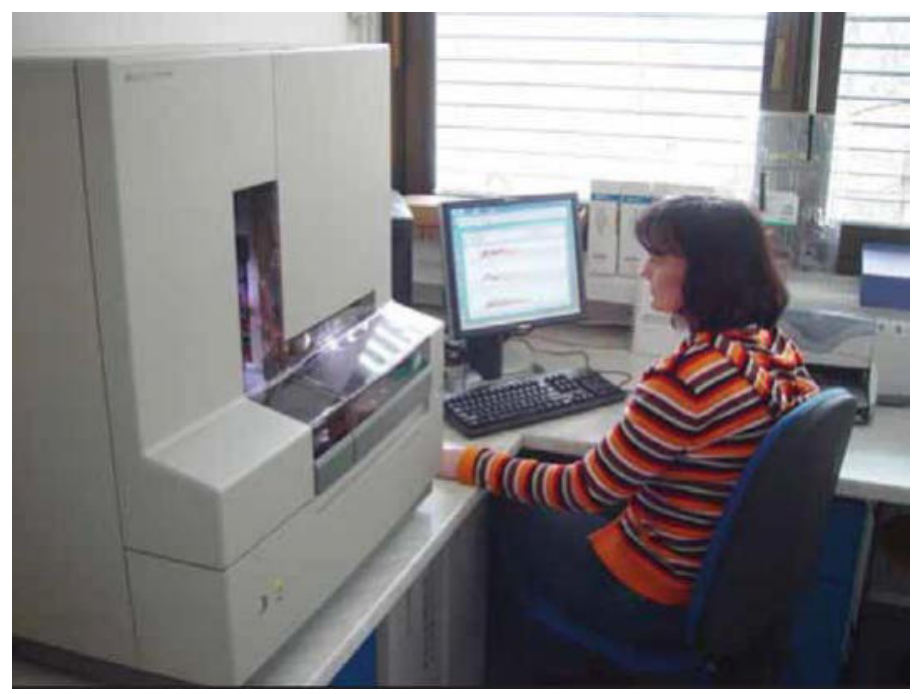

Slika 5. Prvi automatski uređaj za sekvenciranje molekula DNA u Hrvatskoj instaliran 2004. u Laboratoriju za molekularnu genetiku Zavoda za molekularnu biologiju IRB-a koji djeluje kao servisna djelatnost koju su uspostavile Vera Gamulin i Helena Četković (https://www.irb.hr/Istrazivanja/ Kapitalna-oprema/DNA-sekvenator-ABI-PRISM-R-3100-Avant-Genetic-Analyzer).

Slika preuzeta s mrežnoga izvora http://fulir.irb.hr/205/1/Rudjer\%282005\%29vol6_br3_4.pdf

u Hrvatskoj (slika 5). DNA-sekvenator je uređaj kojim se određuje slijed nukleotida u molekuli DNA. Naime, prirodni supstrati za sintezu DNA su nukleotidi. Enzimi koji sintetiziraju DNA mogu ugraditi u rastući lanac i analoge nukleotida, uzrokujući zaustavljanja daljnje sinteze DNA lanca. Svaki analog nukleotida obilježen je drugom fluorescentnom bojom. Na kraju reakcije nastaje smjesa fragmenata DNA koji se razlikuju duljinom samo za jedan nukleotid. Tijekom elektroforeze fluorescentno obilježeni odsječci putuju u okomito postavljenom gelu, a detekcija se provodi sustavom koji uključuje laserski čitač. Signali se automatski pohranjuju i računalno obrađuju.

Istaknuti hrvatski molekularni genetičar, akademik Željko Trgovčević15, od 1964. djelovao je u IRB-u, a doktorirao je pod mentorstvom Ž. Kućana. Isprva je

15 Trgovčević, Željko (Zagreb, 22. V. 1939 - Zagreb, 21. I. 2000), molekularni genetičar. Na Medicinskom fakultetu u Zagrebu diplomirao 1963. i doktorirao 1968. Usavršavao se na Medicinskom fakultetu Sveučilišta Yale (1972-75). Od 1964. djelovao je u IRB-u, gdje je isprva istraživao razgradnju, a potom popravak i replikaciju DNA u ozračenih bakterija. Služeći se složenim tehnikama, u kojima su enzimi za popravak ili replikaciju DNA bili proizvod bakterijskoga genoma, ili su bili uneseni u bakterijsku stanicu preko plazmida ili bakteriofaga, otkrio je uloge pojedinih rekombinacijskih proteina $\mathrm{u}$ tim procesima. Bio je redoviti profesor na PMF-u u Zagrebu, gdje je predavao kolegij Molekulana genetika. Bio je član mnogih međunarodnih i domaćih znanstvenih društava te Nacionalnoga vijeća za znanost. Od 1992. bio je redoviti član HAZU. Nagrađen je Nagradom za znanstveni rad »Ruđer Bošković« 1990. Podatci preuzeti s https://www.enciklopedija.hr/natuknica.aspx?id=62222 (pristupljeno 22. VI. 2020.) 
istraživao razgradnju, a potom popravak i replikaciju DNA u ozračenih bakterija (Trgovčević 1967: 193). Ipak, tek kad je M. Radman otkrio inducirani popravak DNA, tzv. SOS-popravak, postalo je jasno da je degradacija DNA bila pokušaj bakterija da poprave oštećenja genoma nastala zračenjem (Rudež 2013: 73). Trgovčević, služeći se složenim tehnikama, u kojima su enzimi za popravak ili replikaciju DNA bili proizvod bakterijskoga genoma, ili su bili uneseni u bakterijsku stanicu s pomoću plazmida ili bakteriofaga, otkrio je uloge pojedinih rekombinacijskih proteina u tim procesima i znatno pridonio razvoju molekularne genetike u Hrvatskoj. Jedan je od osnivača Zavoda za molekularnu biologiju na IRB-u i dugogodišnji direktor molekularno-biološkoga programa istraživanja Struktura, funkcija i evolucija staničnog genoma. Biokemijska istraživanja spojio je s molekularno-genetičkima te pratio sudbinu bakteriofaga u ozračenoj stanici. Tako je otkrio da radiosenzitivnost bakterije određuju u međusobnoj interakciji dva rekombinacijska sustava: sustav bakterije i sustav faga. Istraživao je uloge pojedinih enzima u tom procesu, a naročito proteina za vezanje jednolančanog DNA enzima RecBCD. U istraživanjima mikrobijalne radiobiologije utvrđeno je da provirusni dio bakterijskoga kromosoma - pod stanovitim uvjetima - može povećati otpornost bakterije-domaćina. Istraživala se i pojava pretvorbe provirusa u virus. Utvrđeno je da se prve faze razvojnoga ciklusa bakteriofaga lambda (to je virus koji parazitira u bakterijama) odvijaju u sustavu in vitro, bez prisutnosti žive stanice, tj. u izoliranim frakcijama stanične membrane i stijenke. Bio je aktivan član Hrvatskoga genetičkog društva (predsjednik 1982-83). Osnovni cilj Društva je okupljanje genetičara i stručnjaka srodnih struka radi unapređivanja svih područja genetike, pružanje stručne i znanstvene pomoći u cilju poboljšanja nastave iz genetike na fakultetima i popularizacije genetike, održavanje javnih sastanaka, predavanja, kolokvija, seminara i tečajeva iz područja genetike, biokemije i molekularne genetike, genetičkoga inženjerstva, mutageneze, oplemenjivanja organizama i populacijske genetike. Također članovi Društva sudjeluju u organizaciji znanstvenih skupova i kongresa, te pružanju stručne pomoći pri izradi pravilnika, ekspertiza i analiza s navedenih znanstvenih područja. Društvo je službeno počelo s radom 1978. godine. Prva predsjednica Društva bila je prof. dr. sc. Ljiljana Zergollern (1978-80), a potom su Društvo vodili akademik Mirko Vidaković (1980-82), akademik Željko Trgovčević (1982-84), akademkinja Sibila Jelaska (1984-87), akademik Andrija Kaštelan (1987-89), dr. sc. Jasenka Pigac (1989-96), prof. dr. sc. Dražena Papeš (19962002), dr. sc. Đurđica Ugarković (2002-07), prof. dr. sc. Jasna Franekić Čolić (2007-11), prof. dr. sc. Verica-Garaj-Vrhovac (2011-15), prof. dr. sc. Hrvoje Šarčević (2015-19) i prof. dr. sc. Ivan Krešimir Svetec (od 2019) ${ }^{16}$. Prvi znanstveni sastanak Hrvatskoga genetičkog društva održan je u Osijeku 1979., a organizirali su ga članovi Poljoprivrednoga instituta u Osijeku koji su tom prigodom uspjeli okupiti velik broj uglednih genetičara i oplemenjivača bilja. Također 1979. u Tučepima je održan kongres

16 Mrežna stranica Hrvatskoga genetičkog društva https://pubweb.carnet.hr/genetika/ 
Ninth Annual Meeting of European Environmental Mutagen Society (EEMS) koji je organizirala profesorica M. Alačević, nakog čega je u Hrvatskoj, Sloveniji i Srbiji počeo nagli razvoj istraživanja na području mutageneze. Hrvatsko genetičko društvo od 2001. dodjeljuje Nagradu »Željko Trgovčević« najboljim mladim znanstvenicima iz područja molekularne biologije. Nagrada se dodjeljuje jednom godišnje mladom znanstveniku za izniman znanstveni rad izrađen u Hrvatskoj i objavljen u vrhunskom časopisu.

Znanstvenici IRB-a uspješni su u komercijalizaciji proizvoda dobivenih genetičkim inženjerstvom. Od 1990-ih znanstvenici Instituta, Lea Vojta i Hrvoje Fulgosi, proučavali su protein TROL, ključan u fotosintezi i biogenezi biljaka (Jurić 2009: 783). Najprije su u biljci uročnjak (lat. Arabidopsis thaliana) pronašli gensku sekvencu za taj protein, potom su stvarali bilike s eliminiranim genom za TROL, no nedostajala je mogućnost stvaranja antitijela (seruma) za taj protein. Uspjeh je ostvaren 2019. razvojem biotehnološkoga procesa proizvodnje proteina uz pomoć genetičkoga inženjerstva (tehnologijom rDNA), pročišćavanjem proteina i na kraju dobivanjem antitijela za taj protein imunizacijom zečeva. Postoji mogućnost skore komercijalizacije seruma budući da je njegovo korištenje nezaobilazno u istraživanjima fotosinteze, odnosno različitih metoda čišćenja atmosfere, istraživanjima alternativnih izvora energije, fotosinteze $u$ algama i cijanobakterijama te proizvodnji biljaka otpornijih na stres, koja su posljednjih godina iznimno važna zbog klimatskih promjena.

\section{2. 3. Genetičko i proteinsko inženjerstvo na Prirodoslovno-matematičkom fakultetu u Zagrebu}

Biokemija se u Hrvatskoj isprva razvila u IRB-u i to u radioizotopnom laboratoriju Dine Keglević i radiobiološkom Branimira Miletića u kojem je svoj rad započeo Ž. Kućan 1958. Osim toga laboratorija, postojala su barem još tri biokemijska laboratorija u IRB-a koje su vodili profesori Sveučilišta u Zagrebu, Mihovil Proštenik, Viktor Hahn i Krešimir Balenović (Rudež 2017: 72). Krajem 1950-ih Balenović je preselio svoj laboratorij s IRB-a na Strossmayerov trg 14. Miletićeva je radiobiologija počivala na koncepciji da treba istraživati oštećenja nasljedne tvari DNA na jednostavnim modelima. Bila je to ponajprije bakterija $E$. coli, a zatim bakteriofag lambda te napokon animalne stanice. U toj skupini celularnih radiobiologa s IRB-a započeo je razvoj molekularne biologije u Hrvatskoj. Kućan je 1983. prešao na PMF kao redoviti profesor biokemije pa se biokemijska znanost ubrzano razvija u Laboratoriju za biokemiju Kemijskoga odsjeka pod njegovim vodstvom, pokrenuvši u svijetu aktualna, istraživanja nukleinskih kiselina i biosinteze proteina. Prof. Kućan je suotkrivač razgradnje DNA u ozračenih bakterija i pokretač istraživanja molekula tRNA u Hrvatskoj. Osnovao je i predavao sve biokemijske kolegije na zagrebačkom PMF-u. Na području molekularne biologije važno je njegovo otkriće 1961. u suradnji s B. Mileti- 
ćem (Miletić 1961: 343) da se dio genetičkoga materijala DNA u ozračenih bakterija metabolički depolimerizira (Miletić 1964: 311), nakon čega se ubrzo počeo baviti istraživanjem prevođenja genetičke poruke tj. biosinteze proteina (Kućan 1966: 229, 1971: 237-251; Trgovčević 1967: 193), a osobito uloge tRNA u tom procesu (Kućan 1971: 177; Nöthig-Laslo 1985: 941). Pokazao je da inhibicija biosinteze proteina antibioticima in vitro ovisi o sastavu prijepisa genetičke poruke, tj. o mRNA (Kućan 1964: 516). Izolirao je tirozil-tRNA-sintetazu, proučavao interakcije toga enzima s tRNA i odredio ulogu nekih nukleotida u biološkoj funkciji tRNA. Studirao je i konformacijske promjene tRNA i pronašao koji su dijelovi te makromolekule pri čitanju genetičke šifre u kontaktu s ribosomom. Pronašao je nadalje da poliamin spermin pospješuje točnost i efikasnost čitanja genetičke poruke specifičnim vezivanjem na tRNA te da istim mehanizmima sprječava krivo čitanje kodona izazvano aminoglikozidnim antibioticima.

Eksprimiranje, pročišćavanje i analiziranje rekombinantnih proteina u $\mathrm{Hr}$ vatskoj sustavno je započelo tijekom 1990-ih godina u Kućanovu laboratoriju u Zavodu za biokemiju PMF-a, u doba djelovanja profesorice I. Weygand-Đuraševićc ${ }^{17}$. Da je Weygand-Đurašević bila fascinirana znanstveno-utemeljenim odnosom strukture i funkcije proteina, dokazuje čitav niz primjera iz njezina interdisciplinarnog znanstvenog rada na području biokemije i molekularne biologije (Weygand-Đurašević 1996: 2455; Lenhard 1997: 1136, 1999: 721; Rokov 1998: 497; Landeka 2000: 160; Gruić-Sovulj 2001: 161; Bilokapić 2004: 694, 2006: 2498; Godinić 2007: 2788; Godinić Mikulčić 2011: 3396, 2014: 5191; Greber 2012: 145). Osobito se bavila aminoacil-tRNA-sintetazama te u svrhu njihova istraživanja klonira gene za te enzime metodama genetičkoga inženjerstva. Začetnica je proteinskoga inženjerstva u Hrvatskoj. Aminokiselinski slijed proteina odnosno njegova primarna struktura zapisana je u genima, odnosno u molekuli DNA. Iako neki sadrže informaciju samo za molekule RNA, geni izražavaju svoj funkcionalni efekt stvaranjem proteina. Proteinsko inženjerstvo uključuje dizajniranje novih varijanti proteina pomoću metoda genetičkog inženjerstva i rekombinantne tehnologije DNA čime se preinačuju kemijska, fizikalna i biološka svojstva proteina. I. Weygand-Đurašević prva uvodi u uporabu mnoge kvašče-

17 Weygand-Đurašević, Ivana (Osijek, 15. VI. 1952 - Zagreb, 7. IV. 2014), biokemičarka. Školovala se u Zagrebu, gdje je 1975. diplomirala na PMF-u. Iste godine zaposlila se kao asistentica u Zavodu za biokemiju PMF-a. Stupanj magistre znanosti iz molekularne biologije stekla je 1978., a doktorice znanosti 1981. Za docenticu je izabrana 1988. godine, za izvanrednu profesoricu 1995., a za redovnu profesoricu 2000. U prosincu 2005. izabrana je u trajno zvanje redovne profesorice. Objavila je ukupno 60 znanstvenih radova, radovi su joj citirani oko 600 puta. Suautorica je udžbenika i stručnih radova. Vodila je nekoliko domaćih projekata, a na sedam inozemnih projekata bila je ili glavni koordinator ili voditelj hrvatskoga tima. Bila je predstojnica Zavoda za biokemiju PMF-a u Zagrebu (1999-2014) i voditeljica smjera Biokemija na poslijediplomskom studiju. Godine 2002. izabrana je za članicu suradnicu HAZU, a 2012. za redovitu članicu. Dobitnica je Državne nagrade za znanost za 2005. godinu. Podatci preuzeti s http:// info.hazu.hr/hr/clanovi_akademije/osobne_stranice/weygand/weygand_biografija/ (pristupljeno 18. VI. 2020). 
ve i bakterijske rekombinantne vektore za ekspresiju proteina i pohranjuje ih $\mathrm{u}$ zbirku Zavoda za biokemiju. U Hrvatsku uvodi u uporabu plazmidne vektore tipa pET u koji su željeni geni ugrađeni pod kontrolom inducibilnog promotora u svrhu prekomjerne biosinteze proteina (ekspresije) u najčešće heterolognom domaćinu. Potiče i usmjerava suradnike prema radu na konstrukciji novih plazmidnih vektora za učinkovitiju prekomjernu ekspresiju proteina. Nakon stjecanja diplome 1975. na PMF-u u Zagrebu, odmah je u laboratoriju prof. Kućana počela istraživati molekule tRNA, molekule ključne u translaciji (prevođenju genetičke informacije). Vođena silnom ambicijom, znatiželjom i strašću da nauči novu tehnologiju, 1984. odlazi na Sveučilište Yale u SAD-u, gdje se već usavršavala V. Gamulin, i tamo usvaja najsuvremenije metode genetičkoga inženjerstva koje su joj omogućile prekrajanje molekula tRNA i proteina po vlastitoj zamisli. Na Sveučilištu Yale klonirala je gen za kvaščevu seril-tRNA-sintetazu, što je i posvema odredilo smjer njezina budućeg rada. Po povratku u Hrvatsku, uvela je u uporabu suvremene metode genetičkoga inženjerstva i ustanovila metode proteinskoga inženjerstva koje su omogućile uvođenje željene promjene na točno određenom mjestu u makromolekuli i ekspresiju takva proteina u stanici. Prof. Weygand-Đurašević trajno je težila izvrsnosti i takve težnje naročito je poticala u mlađih suradnika (slika 6). Razvila je intenzivnu suradnju Laboratorija s mnogim istraživačkim institucijama u zemlji i inozemstvu (s Dieterom

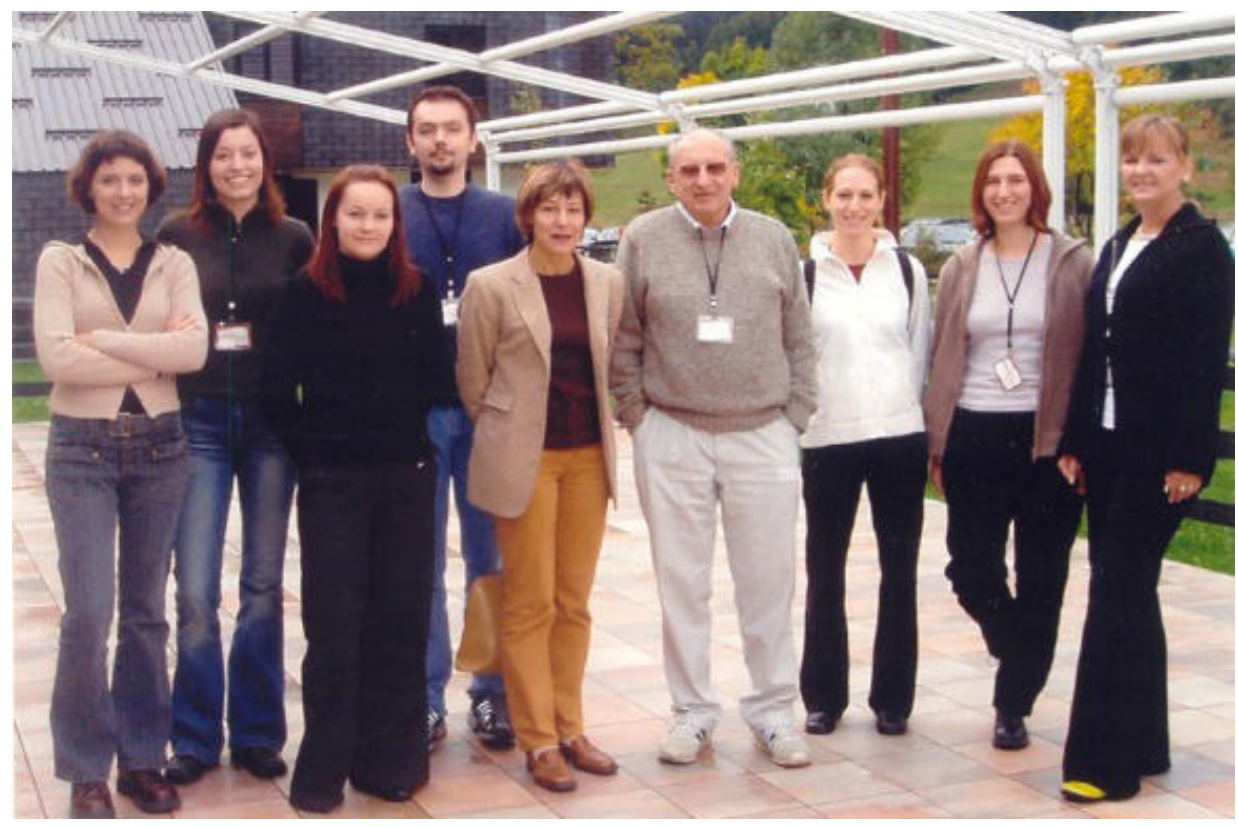

Slika 6. Članovi Zavoda za biokemiju PMF-a u Zagrebu na Kongresu Hrvatskoga društva za biokemiju i molekularnu biologiju 2004. S lijeva udesno: Ita Gruić Sovulj, Jelena Jarić, Vlatka Godinić Mikulčić, Boris Lenhard, Ivana Weygand-Đurašević, Želiko Kućan, Sonja Lesjak, Jasmina Rokov Plavec i Irena Landeka (privatna zbirka V. Godinić Mikulčić) 
Söllom sa Sveučiliša Yale i Nenadom Banom ${ }^{18}$ s ETH u Zürichu, koji su i dopisni članovi HAZU, te s Gregorom Anderluhom s Nacionalnoga instituta za kemiju iz Ljubljane). U razdoblju 1998-2005. bila je kontakt osoba (engl. liaison officer) Internacionalnoga centra za genetičko inženjerstvo i biotehnologiju (ICGEB; Trst).

Uporaba tehnika rekombinantne DNA donijela je velik i važan napredak u molekularnoj biologiji tako da se na Fakultetima brzo mijenjaju nastavni programi i osnivaju novi zavodi. Najmlađi zavod u okviru Biološkoga odsjeka PMF-a u Zagrebu jest Zavod za molekularnu biologiju osnovan 1989. godine ${ }^{19}$. Glavni doprinos utemeljenju Zavoda dali su profesori i suradnici Biološkoga odsjeka (Sibila Jelaska, Dražena Papeš, Marijana Krsnik-Rasol, Biserka Nagy, Nikola Juretić, Greta Pifat-Mrzljak, Ž. Trgovčević, Jasna Ban, V. Delić, Ž. Kućan, I. Weygand-Đurašević). Njihova nastojanja svesrdno su podržavali nastavnici drugih odsjeka Fakulteta, u prvom redu tadašnji predstojnik Zavoda za biokemiju Ž. Kućan, a prva predstojnica Zavoda je bila akademkinja S. Jelaska ${ }^{20}$. Na novoosnovanome Zavodu za molekularnu biologiju istoga fakulteta, utemeljila je Laboratorij za kulturu biljnoga tkiva. Glavno je pod-

18 Ban, Nenad (Zagreb, 3. V. 1966), molekularni biolog. Diplomirao je molekularnu biologiju na PMF-u u Zagrebu (1990). Doktorirao iz biokemije na Kalifornijskom sveučilištu u Riversideu (1994). Od 1995. do 1999. djelovao na Sveučilištu Yale u New Havenu. Godine 1995. već je bio kristalografski stručnjak s više od deset radova u vrhunskim časopisima. Na Odjelu molekularne biofizike i biokemije Sveučilišta Yale, odnosno u laboratoriju profesora Thomasa Steitza, započinje rad na strukturi velike ribosomske podjedinice. Struktura je bila riješena u proljeće 2000. Banova struktura velike ribosomske podjedinice pružila je prvi uvid u građu neke stanične ribonukleoproteinske čestice (Ban 2000: 905). Razotkrila je da je aktivno mjesto ribosoma građeno isključivo iz RNA, pa je ribosom zapravo ribozim. Za to je otkriće bio jedan od dobitnika Nagrade Newcomb-Cleveland, koju dodjeljuje Američko društvo za unapređenje znanosti. Njegovi se rezultati smatraju prekretnicom u istraživanju sinteze proteina. Ubrzo nakon što je otkriće objavljeno, ujesen 2000., preselio se u Zürich. Na Tehničkoj visokoj školi (ETH), u Zürichu gdje je radio kao profesor strukturne molekularne biologije, 2007. je godine, u dobi od samo 41 godine, postao redovitim profesorom. Biokemijskim, elektronskomikroskopskim i kristalografskim metodama istražuje ribosome, velike enzime i druge stanične supramolekularne strukture. (http:// info.hazu.hr/hr/clanovi_akademije/osobne_stranice/n_ban; pristupljeno 18. VI. 2020).

19120 godina nastave prirodoslovlja i matematike na Sveučilištu u Zagrebu (21. travnja 1876 21. travnja 1996).

20 Jelaska, Sibila (Ljubljana, 19. IX. 1938), biologinja. Gimnaziju završila 1957. u Zagrebu, gdje je diplomirala biologiju 1962. te 1972. doktorirala tezom Morfogeneza eksplantata bundeve uzgajanih in vitro na PMF-u. Od 1963. bila je asistentica, a 1975-77. znanstvena suradnica u Institutu za botaniku. Od 1977. bila je znanstvena suradnica u Botaničkom zavodu PMF-a, 1980. postala je višom znanstvenom suradnicom, 1985. znanstvenom savjetnicom, a 1987. redovitom profesoricom. Nakon utemeljenja Zavoda za molekularnu biologiju 1989. prešla je onamo kao prva predstojnica. Organizirala je laboratorij za kulturu biljnih stanica na PMF-u. Usavršivala se u Parizu u Laboratoire de biologie cellulaire (1972), studijski boravila u SAD-u, Engleskoj, Njemačkoj, Švedskoj i Francuskoj, a 1990-91. bila je gostujuća istraživačica na Sveučilištu u Berkeleyju. Umirovljena je 1999. Članica je International Association of Plant Tissue Culture od 1974. te 1976-90. nacionalna korespondentica za tadašnju Jugoslaviju, predsjednica Hrvatskoga društva za biljnu fiziologiju 1978-82, Jugoslavenskoga društva za biljnu fiziologiju 1985-87. i Bioetičkoga povjerenstva za praćenje genetski modificiranih organizama pri Vladi RH od 1999. Redovita je članica HAZU od 1997. te dobitnica Nagrade grada Zagreba 1984. i Nagrade za životno djelo 2000. Podatci preuzeti s http://hbl.lzmk.hr/clanak.aspx?id=8357 (pristupljeno 8. VII. 2020). 
ručje njezina znanstvenoga rada razvojna biologija bilja. Važne je rezultate postigla u indukciji somatske embriogeneze te regeneraciji i transformaciji biljnih vrsta u kulturama in vitro (Jelaska 1981: 285-292, 1984: 125; Mihaljević 2003: 313; Leljak-Levanić 2004: 120, 229; Bauer 2015: 3). Začetnica je primjene različitih tehnika kulture biljnoga tkiva za potrebe klonskoga razmnožavanja biljnih vrsta i ozdravljivanja sadnica u Hrvatskoj. Aktivnost Zavoda u području biljne biotehnologije temeljila se na genetičkom inženjerstvu. Transformacija posredovana agrobakterijama primjenjuje se na više bilinih vrsta (hren, bundeva, četinjače, ukrasna kopriva, šećerna repa) u istraživanju metabolizma sekundarnih produkata (peroksidaze, ružmarinska kiselina, taksol) u transgeničnom tkivu, te prilikom istraživanja diferencijacije i regeneracije biljne stanice. Istražuje se mehanizam razvoja i regeneracije biljnoga organizma in vitro u kontroliranim uvjetima radi dobivanja klonskih i/ili genetički preinačenih biljaka, proučavaju se mehanizmi razvoja biljaka na razini genske aktivnosti i epigenetičkih mehanizama u određenim fazama razvoja biljke (Dunja Leljak Levanić, Nataša Bauer, Nenad Malenica, Višnja Besendorfer), rabi se sustav CRISPR-Cas (Ivana Ivančić-Baće, Vlatka Zoldoš, Maja Matulić, P. Korać). Istraživanja u Zavodu za molekularnu biologiju zasnovana su na suvremenim metodama molekularne biologije, biokemije, stanične biologije, genetike, biofotonike i bioinformatike, te se provode na različitim modelnim organizmima: bakterijama, kvascima, diktiostelidima, beskralježnjacima, biljkama, laboratorijskim životinjama i stanicama sisavaca u kulturi. Područja istraživanja mogu se sažeti u nekoliko širih tema: replikacija, rekombinacija i popravak DNA, odnosno procesi vezani uz održavanje genetičkoga materijala, genetička varijabilnost i stvaranje novih vrsta; organizacija genoma i repetitivne sekvence DNA; transkripcija i translacija genetičke poruke, odnosno procesi vezani uz ekspresiju genetičke poruke; molekularni procesi vezani uz regulaciju stanične diobe, diferencijacije, rasta i starenja; molekularni procesi uključeni u stanični odgovor na citostatike i antibiotike, kao i na nastanak rezistencije; genetička pozadina i regulatorni mehanizmi neurotransmisije; molekularni regulatori fotosinteze; fiziologija, biokemija i strukturna biologija biljnih hormona; dinamički procesi u citoskeletu; evolucija gena i genoma kao trajni proces u živom svijetu. Važna je uloga Zavoda za molekularnu biologiju u nastavi i poučavanju studenata u temeljitu razumijevanju bioloških procesa na molekularnoj razini i rasvjetljavanju osnovnih zakonitosti života, kao i osposobljavanju mladih stručnjaka za profesionalni rad u molekularnim bioznanostima, uključujući genetičko inženjerstvo, biomedicinu i biotehnologiju.

\section{2. 4. Primjena genetičkoga inženjerstva u Hrvatskoj}

Osim u farmaceutskoj industriji, genetičko inženjerstvo danas se u hrvatskoj znanstvenoj zajednici često rabi u dizajniranju proteina de novo ili u preinačivanju strukture pojedinih dijelova proteina u svrhu eksprimiranja, pročišćavanja i analiziranja rekombinantnih proteina, posebice fuzijskih (proteinsko inženjerstvo). Proteinskim inženjerstvom uvode se promjene $\mathrm{u}$ aminokiselinskom sastavu proteina, što omogu- 
ćuje dobivanje proteina novih svojstava, odnosno dizajniranih proteina. U Zavodu za biokemiju PMF-a, prof. Weygand-Đurašević otkrila je, sa svojim suradnicima (slika 6), novu skupinu i trodimenzionalnu strukturu atipičnih seril-tRNA-sintetaza (Silvija Bilokapić), analizirala međudjelovanja proteina i otkrila nove makromolekularne komplekse aminoacil-tRNA-sintetaza i ribosoma (Vlatka Godinić Mikulčić, Sanda Ročak), analizirala evoluciju i strukturu seril-tRNA-sintetaza (Boris Lenhard), istraživala nekanonske uloge homologa seril-tRNA-sintetaza izvan translacije i biosinteze proteina (Marko Močibob) te analizirala razlike u mehanizmu aminoacilacije aminoacil-tRNA-sintetaza (Ita Gruić Sovulj, Jelena Jarić). Od tada pa do danas u Zavodu za biokemiju PMF-a pripremljeno je više od stotinu rekombinantnih proteina od kojih su mnogima svojstva bila preinačena genetičkim i proteinskim inženjerstvom, a rabe se za detalinu analizu strukture i funkcije proteina aminoacil-tRNA-sintetaza te za određivanje njihova unutarstaničnog smještaja (Jasmina Rokov Plavec). U novije su doba u Hrvatskoj, mahom na fakultetima (Farmaceutsko-biokemijskom fakultetu, Zagreb; PBF-u, Zagreb; Medicinskom fakultetu, Rijeka; Medicinskom fakultetu, Zagreb; PMF-u, Zagreb; Fakultetu kemijskoga inženjerstva i tehnologije, Zagreb; PMF-u, Split; Medicinskom fakultetu, Osijek), u Centru za istraživanje i prijenos znanja u biotehnologiji Sveučilišta u Zagrebu, i u institutima (Mediteranskom institutu za istraživanje života, IRB-u), u fokusu istraživanja: sustav CRISPR-Cas (Ivana Ivančić Baće, Vlatka Zoldoš, Marta Popović, Sonja Levanat, Marin Kovačić, P. Korać), primjena tehnika genetičkoga inženjerstva u biljnoj funkcionalnoj genomici i epigenetici (S. Jelaska, N. Malenica, D. Leljak Levanić, N. Bauer, Petra Peharec, Biljana Balen, Dubravko Pavoković), molekularna bilina biologija i biotehnologija (H. Fulgosi, L. Vojta), biologija streptomiceta (Andreja Mikoč, Dušica Vujaklija), istraživanje gena i proteina spužvi (Helena Četković), struktura i funkcija telomera (Ivica Rubelj), regulacija transkripcije (Marija-Mary Sopta), mehanizmi genetičke rekombinacije i rekombinacijskoga popravka DNA (Ksenija Zahradka, Davor Zahradka), istraživanje biljnih regulatora rasta (M. Sopta, Dunja Šamec, Branka Salopek Sondi), regenerativna medicina (Marijastefanija Antica, Slobodan Vukičević), neurokemija i molekularna neurobiologija (Lipa Čičin-Šain), istraživanje molekularnih i staničnih mehanizama odgovornih za nastanak raka (Janoš Terzić, Ivana Novak Nakir), proučavanje osobitosti sekvenci i evolucije satelitnih DNA (Miroslav Plohl, Nevenka Meštrović Radan, Brankica Mravinac), molekularna medicina (Marijeta Kralj, Koraljka Gall Trošelj, Silva Katušić Hećimović, Tihomir Balog, Nela Pivac, Oliver Vugrek, Petar Ozretić, Neven Žarković, Sanja Kapitanović, Neda Slade, Maja Herak Bosnar, Maja Matulić), primjena u dijagnostici, forenzičnoj DNA analizi i istraživanju glikoproteina (Gordan Lauc, Dragan Primorac), analize istraživanja strukture, dinamike i funkcije staničnoga skeleta (Igor Weber, Iva Tolić), evolucijska genetika (Đurđica Ugarković, Kruno Brčić-Kostić i Tomislav Domazet-Lošo), razvoj rekombinantnih virusnih vektora (Andreja Ambriović Ristov, Dragomira Majhen), razvoj rekombinantnih cjepiva (Stipan Jonjić), opleme- 
njivanje industrijskih mikroorganizama (I-K. Svetec, J. Franekić Čolić, Božidar Šantek, Anita Slavica), proizvodnja rekombinantnih proteina u životinjskih staničnih linija (Igor Slivac, Zlatko Kniewald) te u tehnologiji antibiotika, enzima, probiotika i starter kultura (Jagoda Šušković, Blaženka Kos).

\section{2. 5. Nastava genetičkoga inženjerstva na fakultetima u Hrvatskoj}

U nastavku se ističe važnost i uloga nastave iz područja genetičkoga inženjerstva u Hrvatskoj. PBF u Zagrebu, Zavod za biokemiju i Zavod za molekularnu biologiju PMF-a u Zagrebu, Farmaceutsko-biokemijski fakultet u Zagrebu, Medicinski fakultet u Zagrebu, Agronomski fakultet u Zagrebu, PMF u Splitu, Medicinski fakultet u Splitu, Sveučilište u Rijeci i Sveučilište u Osijeku imali su važnu ulogu u obrazovanju stručnjaka u području genetičkoga inženjerstva u Hrvatskoj, održavajući nastavu koja uključuje pojedina poglavlja genetičkoga inženjerstva. Početci razvoja mikrobne genetike na Zagrebačkom sveučilištu povezani su s osnutkom nekoliko studija koje je potaknula profesorica V. Johanides, začetnica biotehnologije u Hrvatskoj (Šušković 2019: 438). M. Alačević, mikrobiološka inženjerka, stručnjakinja za mikrobiološku genetiku u prehrambenoj i kemijskoj industriji, u Zagrebu je na PBF-u predavala kolegije iz genetike mikroorganizama. Bila je predstojnica Zavoda za biokemijsko inženjerstvo 1990-95. te voditeljica Laboratorija za biologiju i genetiku mikroorganizama 1979-94. Nakon umirovljenja M. Alačević (1994) pročelnica Laboratorija postala je profesorica Jasna Franekić Čolić, a od 2011. tu je dužnost preuzeo profesor Ivan-Krešimir Svetec. Na PBF-u danas se predaju sljedeći kolegiji: Genetičko inženjerstvo na preddiplomskom studiju (I.-K. Svetec), gdje se daju osnovni pojmovi genetičkoga inženjerstva, objašnjava područje primjene i implikacije na ljudsko društvo, uspoređuju metodologije oplemenjivanja organizama klasičnim metodama i metodama genetičkoga inženjerstva te daju konkretni primjeri ekspresije humanih proteina u bakteriji, zatim Mikrobna genetika i geneticko inženjerstvo na doktorskom studiju (I.-K. Svetec), Genetika eukariota na diplomskom studiju (I.-K. Svetec), GMO u proizvodnji hrane na diplomskom studiju, gdje se daje uvid u rasprostranjenost GMO u svijetu, karakteristike i primjena GM-mikroorganizama u proizvodnji hrane, Molekularna genetika na preddiplomskom studiju (I.-K. Svetec), Biotehnologija I - preddiplomski (A. Slavica), gdje se daje pregled bioprocesa koji se zasnivaju na rDNA tehnologiji, Molekularna genetika biosinteze antibiotika na doktorskom studiju (nositelj Jurica Žučko), Biotehnološka primjena i tehnologija stanica sisavaca na doktorskom studiju (Višnja Gaurina Srček, suradnici I. Slivac, Z. Kniewald i Kristina Radošević), Osnove tkivnog inženjerstva na diplomskom studiju (I. Slivac) te Proteinsko inženjerstvo (Irena Landeka Jurčević). I.-K. Svetec predaje kolegij Genetički modificirane biljke u proizvodnji hrane na Agronomskom fakultetu Sveučilišta u Zagrebu na diplomskom studiju Agroekologija/Mikrobna biotehnologija u poljoprivredi. Na 
preddiplomskom studiju na Agronomskom fakultetu Sveučilišta u Zagrebu, profesor Ino Čurik u kolegiju Osnove oplemenjivanja domaćih životinja na Agronomskom fakultetu, među ostalim, objašnjava ulogu i značenje kloniranja i genetičkoga inženjerstva, a u obliku seminara predviđena je rasprava o etičkim postavkama i ograničenjima primjene kloniranja i genetičkoga inženjeringa u oplemenjivanju domaćih životinja (I. Čurik). Na diplomskomu studiju istoga fakulteta, u kolegiju Uzgoj i sustavi proizvodnje mesa peradi i jaja daje se pregled mogućnosti selekcije i genetičkoga inženjerstva u stvaranju suvremenih linija i hibrida peradi (Zlatko Janječić).

Ž. Kućan utemeljio je i predavao sve biokemijske kolegije na PMF-u u Zagrebu. I. Weygand-Đurašević također je predavala niz biokemijskih kolegija, napose onih koji su uključivali poglavlja iz genetičkoga inženjerstva. Od 1993. predavala je temeline biokemijske kolegije na dodiplomskom studiju PMF-u u Zagrebu za studente kemije i za studente molekularne biologije (Biokemija, Opća Biokemija, Biokemija I, Biokemija II, Biokemija III: Biosinteza proteina). Predavala je i niz specijaliziranih kolegija na diplomskom i poslijediplomskom studiju: Ekspresija gena $i$ analiza genskih produkata, Genetičko i proteinsko inženjerstvo, Kloniranje gena, Metode rekombinantne DNA, Nukleinske kiseline i genetička informacija (s Ž. Kućanom). S prof. Kućanom i dr. sc. Jernejem prevela je opsežan udžbenik Biokemija (Berg 2013) s engleskog. Nastava na PMF-u iz područja biokemije isprva se odvijala na Akademičkom trgu (danas Strossmayerov trg broj 14). Ovdje vrijedi istaknuti da je nacrt zgrade prema Janečekovim ${ }^{21}$ uputama izradio arhitekt Herman Bollé. Zgrada se započela graditi 1883., a dovršena je već sljedeće godine, pa su u njoj bili smješteni Zavod za anorgansku kemiju, Zavod za biokemiju i Zavod za analitičku kemiju PMF-a u Zagrebu. U toj se zgradi nastava biokemije održavala do 2005. Kada su se ovi zavodi PMF-a u Zagrebu preselili na novu lokaciju na Horvatovac (2005), zgrada je, po odluci Sabora, pripala HAZU. Predstojnik Zavoda za biokemiju 1988. postao je Ž. Kućan, koji je na toj dužnosti ostao do 1995., kada se Zavod za organsku kemiju i biokemiju podijelio na dva zavoda: Zavod za biokemiju s predstojnikom Ž. Kućanom (do 1999) i Zavod za organsku kemiju s predstojnicom Srđankom Tomić-Pisarović. Predstojnica Zavoda za biokemiju 1999-2014. bila je prof. Weygand-Đurašević, nakon koje je tu dužnost preuzela profesorica I. Gruić Sovulj (2014-18), a od 2018. predstojnica Zavoda za biokemiju je profesorica J. Rokov Plavec. Danas se na Zavodu za biokemiju predaje nekoliko kolegija povezanih s genetičkim inženjerstvom i suvremenim metodama u molekularnoj biologiji i biokemiji. U okviru biokemijske grane istraživačkog smjera diplomskog studija kemije studenti slušaju: Genetičko i proteinsko inženjerstvo (J. Rokov Plavec), Genomika i bioinformatika (M. Močibob), Mehanizmi katalize u biološkim sustavima (I. Gruić Sovulj), Stanična biokemija (M. Dulić), Modeliranje biomakromolekula (A. Maršavelski). Uz teorijska znanja, studentima se

${ }^{21} \mathrm{http}: /$ hbl.lzmk.hr/clanak.aspx?id=125 
pružaju praktična znanja iz genetičkoga inženjerstva u okviru kolegija Viši praktikum biokemije, gdje studenti kloniraju gene, pripremaju rekombinantne ekspresijske vektore te eksprimiraju i pročišćavaju rekombinantne proteine. Kolegij Suvremena biokemijska istraživanja $i$ njihova primjena omogućuje studentima nastavničkoga smjera biologije i kemije da, nakon zaposlenja u školi, na znanstveni način mogu diskutirati s učenicima osnovnih i srednjih škola o društveno izazovnim temama povezanih s genetičkim inženjerstvom. Metode i primjene genetičkoga inženjerstva neizostavni su dio i mnogih kolegija na biokemijskom smjeru doktorskoga studija kemije na PMF-u.

Uporaba tehnologije rekombinantne DNA donijela je znatan napredak u molekularnoj biologiji tako da se na Fakultetima brzo mijenjaju nastavni programi i osnivaju novi zavodi. Zavod za molekularnu biologiju osnovan je 1989. u okviru Biološkoga odsjeka PMF-a u Zagrebu, gdje se danas održava glavnina predavanja s temama genetičkoga inženjerstva. Brojni znanstvenici iz drugih ustanova (IRB, Institut za tumore, PLIVIN Istraživački institut), uz postojeći kadar (S. Jelaska, D. Papeš, M. Krsnik-Rasol), bili su angažirani za predavanja koja su činila sadržaj novoga studija molekularne biologije na PMF-u u Zagrebu Sveučilišta u Zagrebu (G. PifatMrzljak, Ž. Trgovčević, J. Ban, B. Nagy, V. Delić, Ž. Kućan, I. Weygand-Đurašević). Prof. Vladimir Delić, znanstveni savjetnik Istraživačkoga instituta PLIVA, bio je ujedno i profesor na Zavodu za molekularnu biologiju Biološkog odsjeka PMF-a u Zagrebu. Od 1988. bio je nositelj kolegija Genetičko inženjerstvo u biotehnologiji i Osnove biotehnologije na PMF-u u Zagrebu, a od 1989. predaje i na PBF-u. Autor je sveučilišne skripte Genetičko inženjerstvo (osnove manipulacije genima) (Delić 1997). Akademkinja S. Jelaska autorica je udžbenika Kultura biljnih stanica i tkiva - Temeljna istraživanja i primjena (Jelaska 1994). U okviru znanstvenih istraživanja i predavanja koja uključuju genetičko inženjerstvo, veliki doprinos Zavodu poslije je dao dr. sc. Srećko Jelenić, koji se bavio istraživanjem procesa prijenosa željenih gena na unaprijed određeno mjesto biljnoga genoma i molekularnim aspektima homologne rekombinacije u prokariotskom i eukariotskom genomu. U spomen na njega i njegov iznimno kvalitetan nastavni rad iz područja biologije na sveučilištu i školama, Biološki odsjek PMF-a u Zagrebu dodjeljuje Nagradu »Srećko Jelenić« najboljem nastavniku Biološkoga odsjeka po izboru studenata. Na Biološkom odjeku PMF-a u Zagrebu danas se predaju sljedeći kolegiji iz područja suvremenoga genetičkoga inženjerstva: Modelni organizmi u molekularnoj biologiji (nositelji S. Gajović i M. Matulić), Osnove genetičkog inženjerstva (nositelj A. Vojta), Metode istraživanja proteina (nositelj B. Balen), Genetika (nositelji V. Zoldoš i M. Pavlica), Biokemija 2 (J. Rokov Plavec), Molekularna genetika (I. Ivančić Baće), Genomi (P. Korać), Metode istraživanja nukleinskih kiselina (M. Ćurković Perica, M), Metode istraživanja proteina (B. Balen), Uvod u forenzičku biologiju (I. Marijanović), Bioinformatika (K. Vlahoviček), Molekularna biologija biljaka (G. Rusak), Mehanizmi biljnog razvitka (D. Leljak-Leva- 
nić), Primjena GIS-a u biologiji (S. Jelaska), Molekularna biologija stanice (M. Matulić, i A. Vojta), Mutageneza i karcinogeneza (I. Marijanović) Osnove biotehnologije (N. Malenica), Genetičko inženjerstvo u biotehnologiji (N. Bauer), Metode istraživanja u molekularnoj biologiji (I. Marijanović i P. Korać), Molekularna virologija (D. Škorić), Viši praktikum iz biokemije (I. Gruić Sovulj), Biologija matičnih stanica (I. Marijanović), Biologija starenja (I. Rubelj), Genom čovjeka (M. Peričić Salihović), Molekularna dijagnostika (P. Korać), Epigenetika (V. Zoldoš), Filogenija i molekularna sistematika (Z. Liber, V. Besendorfer, T. Nikolić i Z. Šatović), Medicinska genetika (P. Korać) i dr. Također, na PMF-u u Splitu na poslijediplomskom sveučilišnom studiju biofizike predaju se kolegiji s tematikom genetičkoga inženjerstva.

Na Farmaceutsko-biokemijskom fakultetu Sveučilišta u Zagrebu studenti imaju priliku slušati kolegije: Molekularna biologija s genetičkim inženjerstvom (Gordana Maravić Vlahoviček, G. Lauc, Jerka Dumić, Sanja Dabelić, Sandra Šupraha Goreta i Olga Gornik Kljaić), Suvremene biokemijske tehnike (nastavnici S. Dabelić, S. Šupraha Goreta i J. Dumić), Molekulske osnove bolesti i terapije (Karmela Barišić i J. Dumić), Kompleksna genetika (nastavnici S. Dabelić, J. Dumić, G. Maravić Vlahoviček i S. Šupraha Goreta). Na Sveučilištu u Rijeci profesor Siniša Volarević na preddiplomskom sveučilišnom studiju Sanitarno inženjerstvo predaje kolegij Molekularna medicina i biotehnologija. Također na Sveučilištu u Rijeci studenti pohađaju kolegije iz genetičkoga inženjerstva na sljedećim studijima: preddiplomski Biotehnologija i istraživanje lijekova, diplomski Biotehnologija u medicini, diplomski Istraživanje i razvoj lijekova, diplomski Medicinska kemija. Doktorski studij Medicinska kemija nov je poslijediplomski studij, ne samo u Hrvatskoj nego i u široj regiji, kojemu su osnivači partnerske organizacije: Sveučilište u Rijeci, IRB i Fidelta d.o.o., a izvodi se od 2016. kao zajednički studij i u Rijeci i u Zagrebu. Ovaj novi studij rezultat je strategije Sveučilišta i otvaranja doktorskih studija potrebama izvan sveučilišne zajednice te realizacije bilateralnih ugovora o suradnji s IRB-om i Istraživačkim institutom Fidelta d.o.o. Svaka od ovih institucija ulaže u ovaj projekt svoje najbolje znanstvenike i nastavnike, ali i najkvalitetnije specijalizirane laboratorije i opremu. Treba svakako ovdje spomenuti da se na poslijediplomskom interdisciplinarnom sveučilišnom studiju Molekularne bioznanosti koji su 2006. zajednički izradili Sveučilište Josipa Jurja Strossmayera u Osijeku, IRB u Zagrebu i Sveučilište u Dubrovniku, također predaju kolegiji s temom genetičkoga inženjerstva. Temeljna značajka ovoga poslijediplomskoga studija jest funkcionalno integriranje područja biotehničkih znanosti - polje biotehnologija, polje prehrambena tehnologija, polje poljoprivreda (agronomija), područja biomedicine i zdravstva - polje temeljne medicinske znanosti, te područja prirodnih znanosti - polje biologija, polje fizika i polje kemija. Stečena znanja iz genetičkoga inženjerstva na spomenutim preddiplomskim, diplomskim i doktorskim studijima omogućuju zapošljavanje u znanstvenim institucijama (istraživači, asistenti i znanstveni suradnici), u medicinskim, farmaceutskim, dijagnostič- 
kim, forenzičkim i drugim laboratorijima i biotehnološkim kompanijama, u poljoprivredi i šumarstvu, zaštiti prirode i okoliša te u državnim institucijama, ali i u privatnom poduzetništvu.

\section{Zaključak}

Promjene molekula koje se nalaze u sastavu živih sustava osnova su života. Od Watson-Crickova razjašnjenja strukture nasljednoga materijala (1953) do danas traje neprekidan napredak u spoznavanju tajni biološkoga naslijeđa na razini molekularnih pojava. Znanstvena saznanja danas se umnožavaju neviđenom brzinom, a još brže se pretvaraju u sredstva za rješavanje različitih ljudskih izazova. Od znanstvenih otkrića odmah nastaju uređaji i postupci primjenjivi u svakodnevnom životu, čime genetičko inženjerstvo bez odlaganja ulazi u sve pore naše stvarnosti. U Hrvatskoj samo tri godine nakon otkrića strukture deoksiribonukleinske kiseline u IRB-u formira se mala jezgra istraživača koja - u skladu s općim tendencijama istraživanja Instituta u tom razdoblju - počinje ispitivati djelovanje zračenja na DNA. Rad na području molekularne biologije isprva je uključivao istraživanje radiobioloških problema na nivou stanice metodama biofizike, biokemije, mikrobiologije, citologije i genetike. Započeta su istraživanja virusa, bakterija i životinjskih stanica u kulturi. Već 1970-ih, ubrzo nakon otkrića u svijetu, hrvatska farmaceutska industrija i istraživačke skupine okupljene oko IRB-a, farmaceutskoga poduzeća PLIVA i sastavnica Sveučilišta u Zagrebu, napose PBF-a i PMF-a, rabile su tehnologiju rDNA za svoja osnovna i primijenjena istraživanja. Nove tehnike u genetičkom inženjerstvu omogućile su razvoj niza novih procesa koji se prije iz tehničkih razloga nisu mogli ostvariti. Suvremeni genetičari, biotehnolozi, molekularni biolozi i biokemičari u Hrvatskoj, uključujući i njihove istraživačke skupine, svakodnevno u svojem radu rabe i razvijaju metode genetičkoga inženjerstva kako bi ostvarili važna otkrića, a primjenjuju ih i istaknuti hrvatski znanstvenici u svijetu, primjerice Miroslav Radman (otkrio tzv. SOS-popravak DNA), Nenad Ban (otkrio trodimenzionalnu strukturu mnogih molekularnih struktura ribosoma), Igor Štagljar (patentirao tehnologiju MYTH koja omogućuje praćenje međudjelovanja membranskih proteina), Ivan Đikić (zaslužan za mnoga otkrića u liječenju tumora) i drugi.

Često se čini da razvoj i perspektive genetičkoga inženjerstva nisu adekvatno praćene spremnošću društva za prijam ostvarenih rezultata. Naime, znanstvene spoznaje nisu same po sebi ni dobronamjerne ni zlonamjerne, ali one to mogu postati u uporabi zbog interesa određenih skupina. Izuzev direktno financijski zainteresiranih korporacija i uz njih vezanih znanstvenika, ostala znanstvena javnost redovito traži dodatne provjere rizika prije izdavanja dozvola puštanja GMO u okoliš. Usprkos tome, nije ni ispravno ni moguće zaustavljati znanstvena istraživanja i tehnološki razvoj. Stoga se bioetika pojavljuje i djeluje na dodirnim crtama između filozofije, 
znanosti, politike i gospodarstva, kao disciplina čiji su predmet društveno-ekonomski aspekti uporabe suvremenoga znanja o životu, životnim procesima i živim bićima. Posebnu važnost i aktualnost bioetici daje hitna i intenzivna integracija molekularno-biološkoga znanja i GM-proizvoda u razne tokove svjetske ekonomije. Neznanje i nedovoljno znanje ipak su najvažniji izvori masovnoga nediferenciranog straha od genetičkoga inženjerstva.

\section{LITERATURA}

Alačević, Marija, Strašek-Vešligaj, Margareta, Sermonti, Giuseppe (1973). The Circular Linkage Map of Streptomyces rimosus. Microbiology, 77, str. 173-185.

Ban, Nenad i dr. (2000). The complete atomic structure of the large ribosomal subunit at 2.4 A resolution. Science, 289/5481, str. 905-920.

Bauer, Nataša, Vuković, Rosemary; Likić, Saša; Jelaska, Sibila (2015). Potential of Different Coleus blumei Tissues for Rosmarinic Acid Production. Food technology and biotechnology, 53/1; str. 3-10.

Berg, Jeremy M., Tymoczko, John L., Stryer, Lubert (2013). Biokemija. Prev. Ivana Weygand-Đurašević, Branimir Jernej, Željko Kućan. Zagreb: Školska knjiga.

Bilokapić, Silvija, Korenčić, Dragana, Söll, Dieter, Weygand-Đurašević, Ivana (2004). The unusual methanogenic seryl-tRNA synthetase recognizes tRNA ${ }^{\text {Ser }}$ species from all three kingdoms of life. European fournal of Biochemistry, 271/4, str. 694-702.

Bilokapić, Silvija, Maier, Timm, Ahel, Dragana, Gruić-Sovulj, Ita, Söll, Dieter, Weygand-Đurašević, Ivana, Ban, Nenad (2006). Structure of the unusual methanogen seryl-tRNA synthetase reveals a distinct zincdependent mode of substrate recognition. EMBO fournal, 25/11, str. 2498-2509.

Castaldini, Maurizio i dr. (2005). Impact of Bt Corn on Rhizospheric and Soil Eubacterial Communities and on Beneficial Mycorrhizal Symbiosis in Experimental Microcosms. Appl Environ Microbiol., 71/11, str. 6719-6729.

Četković, Helena, Mikoč, Andreja, Müller, Werner E G, Gamulin, Vera (2007). Ras-like small GT-Pases form a large family of proteins in the marine sponge Suberites domuncula. Fournal of Molecular Evolution, 64/3, str. 332-341.

Delić, Vladimir, Šunić, Damir, Vlašić, Drago (1989). Microbial reactions for the synthesis of vitamin C (L-ascorbic acid). U: E. J. Vandamme (ur.), Biotechnology of vitamins, pigments and growth factors, Elsevier applied science, London-New York, str. 299-334.

Delić, Vladimir (1993). Some applications of recombinant DNA technology in pharmaceutical industry. Medicus, 2/1, str. 85-101.

Delić, Vladimir (1997). Genetičko inženjerstvo (osnove manipulacije genima). Prirodoslovno-matematički fakultet, Zagreb, sveučilišna skripta.

Demerec, Milislav (1933). What is a gene? Fournal of Heredity, 24, str. 368-378.

Demerec, Milislav (1948). Origins of bacterial resistance to antibiotics, fournal of Bacteriology, 56, str. 63-74.

Demerec, Milislav (1963). Selfer mutants of Salmonella typhimurium, Genetics, 48, str. 1519-1531.

Durajlija, Sonja, Pigac, Jasenka, Gamulin, Vera (1991). Construction of two stable bifunctional plasmids for Streptomyces spp. and Escherichia coli. FEMS microbiology letters, 83/3, str. 317-321.

Denby, Charles M. i dr. (2018). Industrial brewing yeast engineered for the production of primary flavor determinants in hopped beer. Nature Communications, 9, str. 1-10. 
Đokić, Slobodan i dr. (1986). Erythromycin series. Part 11. Ring Expansion of Erythromycin A Oxime by the Beckmann Rearrangement. Fournal of the Chemical Society, Perkin Transactions 1, str. 1881-1890.

Đokić, Slobodan, Kobrehel, Gabrijela, Lazarevski, Gorjana (1987). Erythromycin series XII. Antibacterial in vitro evaluation of 10-dihydro-10-deoxo-11-azaerythromycin A: Synthesis and structure-activity relationship of its acyl derivatives. Fournal of Antibiotics, 40/7, str. 1006-1015.

Đokić, Slobodan i dr. (1988). Erythromycin Series. Part 13. Synthesis and Structure Elucidation of 10-Dihydro-10-deoxo-11-methyl-11-azaerythromycin A. Fournal of Chemical Research (S), str. $152-153$.

Godbey, Terrance W. (2015). An Introduction to Biotechnology: The Science, Technology and Medical Applications. London: Academic Press, str. 203-204.

Godinić, Vlatka, Močibob, Marko, Ročak, Sanda, Ibba, Michael, Weygand-Đurašević, Ivana. (2007). Peroxin Pex2lp interacts with the C-terminal noncatalytic domain of yeast seryl-tRNA synthetase and forms a specific ternary complex with $\mathrm{tRNA}^{\text {Ser }}$. FEBS fournal, 274/11, str. 2788-2799.

Godinić Mikulčić, Vlatka, Jarić, Jelena, Hausmann, Corinne D., Ibba, Michael, Weygand-Đurašević, Ivana (2011). An Archaeal tRNA-Synthetase Complex that Enhances Aminoacylation under Extreme Conditions. The fournal of biological chemistry, 286/5, str. 3396-3404.

Godinić Mikulčić, Vlatka, Jarić, Jelena, Greber, J., Basil, Franke, Vedran, Hodnik, Vesna, Anderluh, Gregor, Ban, Nenad, Weygand-Đurašević, Ivana (2014). Archaeal aminoacyl-tRNA synthetases interact with the ribosome to recycle tRNAs. Nucleic acids research, 42/8, str. 5191-5201.

Greber, Basil J., Boehringer, Daniel, Godinić Mikulčić, Vlatka, Crnković, Ana, Ibba, Michael, Weygand-Đurašević, Ivana, Ban, Nenad (2012). Cryo-EM Structure of the Archaeal 50S Ribosomal Subunit in Complex with Initiation Factor 6 and Implications for Ribosome Evolution. fournal of molecular biology, 418/3-4, str. 145-160.

Gruić-Sovulj, Ita, Weygand-Đurašević, Ivana, Kućan, Željko (2001). Influence of modified tRNA on the activation of tyrosine catalyzed by tyrosyl-tRNA synthetase from Saccharomyces cerevisiae. Croatica Chemica Acta, 74/1, str. 161-171.

Hranueli, Daslav, Filipović, Mirjana, Pigac, Jasenka, Vešligaj, Margareta (1983). Utjecaj provirusa na biosintezu antibiotika. Kemija u industriji, 32, str. 401.

Hranueli, Daslav, Šnidaršić, Kristina, Alačević, Marija (1984). Značenje genetskog inženjerstva za razvoj biotehnologije. Kemija u industriji, 33, str. 27.

Jelaska, Sibila, Pevalek, Branka, Papeš, Dražena, Devide, Zvonimir (1981). Developmental aspects of long-term callus culture of Vicia faba L. Protoplasma, 105, str. 285-292.

Jelaska, Sibila, Rengel, Zdenko, Cesar, Vera (1984). Plant regeneration from mesocotyl callus of Hordeum vulgare L. Plant Cell Reports, 3/4, str. 125-129.

Jelaska, Sibila (1994). Kultura biljnih stanica i tkiva - Temeljna istraživanja i primjena. Zagreb: Školska knjiga.

Jurić, Snježana, Hazler-Pilepić, Kroata Ana, Tomašić, Ana, Lepeduš, Hrvoje, Jeličić, Branka, Puthiyaveetil, Sujith, Bionda, Tihana, Vojta, Lea, Allen, John F., Schleiff, Enrico, Fulgosi, Hrvoje (2009). Tethering of ferredoxin: NADP+ oxidoreductase to thylakoid membranes is mediated by novel chloroplast protein TROL. Plant journal, 60/5, str. 783-794.

Korać, Petra, Vraneša, Ana, Petrović, Bernardina, Pavlica, Mirjana (2018). Hrvatsko nazivlje molekularne i stanične biologije. Educatio biologiae, 4, str. 69-75.

Kovačić, Marin (2020). Tehnološke zabilješke: CRISPR revolucija na pomolu. Kemija u industriji, 69/3-4, str. 202-203.

Kućan, Željko, Lipmann, Fritz (1964). Differences in chloramphenicol sensitivity of cell-free amino acid polymerization systems, fournal of Biological Chemistry, 239, str. 516-520. 
Kućan, Željko (1966). Inactivation of Isolated Escherichia coli Ribosomes by Gamma Irradiation, Radiation Research, 27, str. 229-236.

Kućan, Željko, Herak, J. N., Pečevsky-Kućan, Ira (1971a). Functional inactivation and appearance of breaks in RNA chains caused by gamma-irradiation of E. coli ribosomes, Biophysical fournal, 11, str. 237-251.

Kućan, Željko, Freude, Kenneth A., Kućan, Ira, Chambers, Robert W. (1971b). Aminoacylation of bisulfite-modified yeast tyrosine tRNA, Nature: New biology, 232, str. 177-179.

Kućan, Željko (1999). Osnovni pojmovi genske tehnologije. U: D. Polšek, K. Pavelić (ur.), Društveni značaj genske tehnologije. Zagreb: Institut društvenih znanosti Ivo Pilar, str. 11-22.

Landeka, Irena, Filipić-Ročak, Sanda, Žinić, Biserka, Weygand-Đurašević, Ivana (2000). Characterization of yeast seryl-tRNA synthetase active site mutants with improved discrimination against substrate analogues. Biochimica et Biophysica Acta, 1480, str. 160-170.

Leljak-Levanić, Dunja, Bauer, Nataša, Mihaljević, Snježana, Jelaska, Sibila (2004). Somatic embryogenesis in pumpkin (Cucurbita pepo L.): Control of somatic embryo development by nitrogen compounds. Fournal of Plant Physiology, 161, str. 229-236.

Leljak-Levanić, Dunja, Bauer, Nataša, Mihaljević, Snježana, Jelaska, Sibila (2004). Changes in DNA methylation during somatic embryogenesis in Cucurbita pepo L. Plant Cell Reports, 23, str. 120-127.

Lenhard, Boris, Filipić, Sanda, Landeka, Irena, Škrtić, Ivan, Söll, Dieter, Weygand-Đurašević, Ivana (1997). Defining the active site of yeast seryl-tRNA synthetase. Fournal of Biological Chemistry, 272/2, str. 1136-1141.

Lenhard, Boris, Orellana, Omar, Ibba, Michael, Weygand-Đurašević, Ivana (1999). tRNA recognition and evolution of determinants in seryl-tRNA synthesis. Nucleic acids research, 27/3, str. 721-729.

Mihaljević, Snježana, Leljak-Levanić, Dunja, Jelaska, Sibila (2003). Factors affecting Agrobacterium-mediated transformation of Picea omorika (Panč.) Purk. somatic embryos. Periodicum Biologorum, 105/3, str. 313-317.

Miletić, Branimir, Kućan, Željko, Zajec, Lj. (1961). Synthesis of DNA in X-irradiated Escherichia coli B, Biochemical and Biophysical Research Communications, 4, str. 343-347.

Miletić, Branimir, Kućan, Željko, Šašel, Lj. (1964). Synthesis of deoxyribonucleic acid in X-irradiated bacteria treated with chloramphenicol, Nature, 202, str. 311-312.

Muller, Hermann J. (1927). Artificial transmutation of the gene. Science, 66, str. 84-87.

Mutak, Stjepan (2016). Od vitamina do antibiotika - sjećanja jednog kemičara II. dio, Kemija u industriji, 65/7-8, str. 359-374.

Nöthig-Laslo, V., Weygand-Đurašević, Ivana, Kućan, Željko (1985). Structural changes of yeast tRNATyr caused by the binding of divalent ions in the presence of spermine. Fournal of biomolecular structure and dynamics, 2, str. 941-951.

Paleyanda, Rekha K. i dr. (1997). Transgenic Pigs Produce Functional Human Factor VIII in Milk. Nature Biotechnology, 15/10, str. 971-975.

Pigac, Jasenka, Alačević, Marija (1979). Mapping of oxytetracycline genes in Streptomyces rimosus. Periodicum Biologorum, 81, str. 575-582.

Pigac, Jasenka, Vujaklija, Dušica, Toman, Zora, Gamulin, Vera, Schrempf, Hildgund (1988). Structural instability of a bifunctional plasmid pZG1 and single-stranded DNA formation in Streptomyces. Plasmid, 19/3, str. 222-230.

Rokov, Jasmina, Söll, Dieter, Weygand-Đurašević, Ivana (1998). Maize mitochondrial seryl-tRNA synthetase recognizes Escherichia coli tRNA ${ }^{\text {Ser }}$ in vivo and in vitro. Plant molecular biology, 38/3, str. 497-502. 
Rudež, Tanja, Pisk, Krunoslav (2017). Institut Ruđer Bošković: Ljudi i događaji 1950-2000. Zagreb: Školska knjiga.

Šerman, Draško (2013). Dr. Milislav Demerc: od Križevaca do Cold Spring Harbora. Prirodoslovlje, 13/1-2, str. 111-137.

Šušković, Jagoda i sur. (2019). Biotehnologija u Hrvatskoj - povijesna baština i suvremeni trendovi. Godišnjak Akademije tehničkih znanosti Hrvatske, str. 438-484.

Trgovčević, Željko, Kućan, Željko (1967). Preferential degradation of gamma-irradiated deoxyribonucleic acid by crude extract of Escherichia coli. International fournal of Radiation Biology, 12, str. 193-194.

Vešligaj, Margareta, Filipović, Mirjana, Pigac, Jasenka, Hranueli, Daslav (1981). Isolation of Streptomyces rimosus Mutants with Reduced Actinophage Susceptibility. Applied and environmental microbiology, 41, str. 986-991.

Zgaga, Zoran, Novak, Srđan (2000) Projekt ljudskog genoma - završetak ili novi početak? Kemija u industriji, 49/6, str. 237-238.

Weygand-Đurašević, Ivana, Lenhard, Boris, Filipić, Sanda, Söll, Dieter (1996). The C-terminal Extension of Yeast Seryl-tRNA Synthetase Affects Stability of the Enzyme and Its Substrate Affinity, fournal of Biological Chemistry, 271/5, str. 2455-2461.

\title{
HISTORICAL AND TECHNOLOGICAL DEVELOPMENT OF GENETIC ENGINEERING IN CROATIA
}

\author{
Vlatka Godinić Mikulčić \\ The Agency for Mobility and EU Programmes, Zagreb \\ vgodinic@yahoo.com
}

\begin{abstract}
The paper provides an overview of concepts and knowledge about genetic engineering and its development in Croatia and abroad from the second half of the $20^{\text {th }}$ century to the present day. Genetic engineering is the biological term that has undergone the greatest conceptual deformations, and therefore some important concepts are unambiguously explained in the paper. As data and documentation on this are not widely available to the public, a systematic overview of the development of genetic engineering in Croatia as well as the roles of individuals, their interactions and contributions is also presented. As early as the 1970s, the Croatian pharmaceutical industry and research institutions in Croatia produced a wave of biotechnological and genetic engineering research and product development. Various research groups, mostly gathered around the constituents of the University of Zagreb (especially the Faculty of Food Technology and Biotechnology and the Faculty of Science), the Ruđer Bošković Institute and PLIVA, use recombinant DNA technology for their basic research. In addition to a chronology of events related to genetic engineering, the paper also describes the work and merits of scientists M. Demerec, V. Johanides, M. Alačević, Ž. Trgovčević, Ž. Kućan, S. Jelaska, V. Gamulin, V. Delić, I. Weygand-Đurašević, Z. Zgaga, S. Jelenić, and others in the field of genetic engineering.
\end{abstract}

Keywords: genetic engineering; gene; recombinant DNA technology; vectors; cloning; pharmaceutical industry; biotechnology 